\title{
Technè
}

La science au service de l'histoire de l'art et de la préservation des biens culturels

40 | 2014

Thérapéia. Polychromie et restauration de la sculpture dans l'Antiquité

\section{A Microcosm of Colour and Shine. The Polychromy of Chryselephantine Couches from Ancient Macedonia}

Un microcosme de couleur et d'éclat. La polychromie des lits de banquets chryséléphantins de la Macédoine antique

Hariclia Brecoulaki, Sophia Sotiropoulou, Christos Katsifas, Andreas G. Karydas and Vicky Kantarelou

\section{OpenEdition Journals}

Electronic version

URL: https://journals.openedition.org/techne/3001

DOI: 10.4000/techne.3001

ISSN: 2534-5168

Publisher

C2RMF

Printed version

Date of publication: 26 November 2014

Number of pages: 8-22

ISBN: 978-2-7118-6218-4

ISSN: 1254-7867

\section{Electronic reference}

Hariclia Brecoulaki, Sophia Sotiropoulou, Christos Katsifas, Andreas G. Karydas and Vicky Kantarelou, "A Microcosm of Colour and Shine. The Polychromy of Chryselephantine Couches from Ancient Macedonia", Technè [Online], 40 | 2014, Online since 24 July 2020, connection on 08 February 2022. URL: http://journals.openedition.org/techne/3001 ; DOI: https://doi.org/10.4000/techne.3001

\section{(c)}

La revue Technè. La science au service de l'histoire de l'art et de la préservation des biens culturels est mise à disposition selon les termes de la Licence Creative Commons Attribution - Pas d'Utilisation Commerciale - Pas de Modification 4.0 International. 


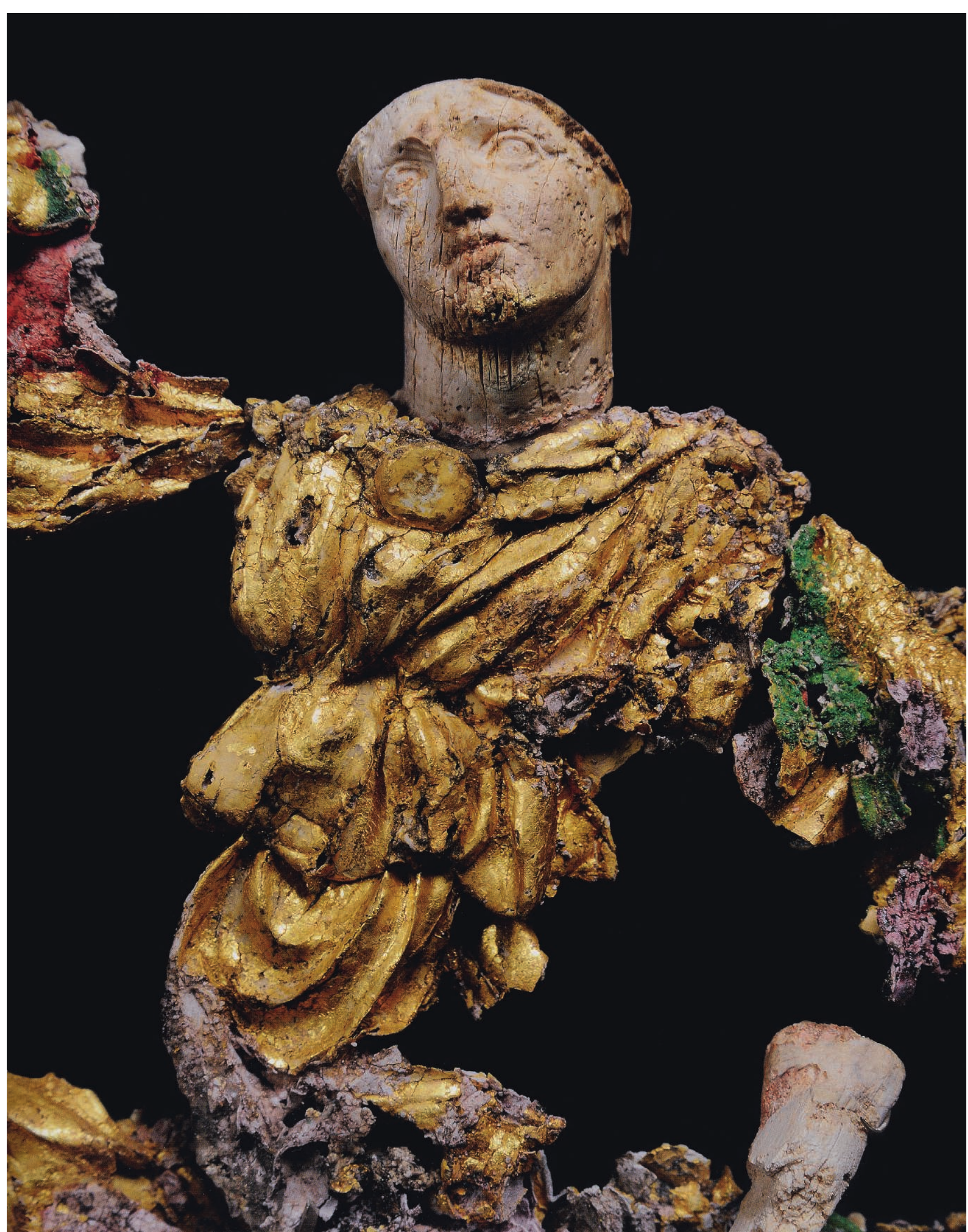

\section{8}


Hariclia Brecoulaki

Sophia Sotiropoulou

Christos Katsifas

Andreas G. Karydas

Vicky Kantarelou

\section{A Microcosm of Colour and Shine. The Polychromy of Chryselephantine Couches from Ancient Macedonia}

Un microcosme de couleur et d'éclat.

La polychromie des lits de banquets

chryséléphantins de la Macédoine antique

\begin{abstract}
The present work examines the polychromy applied to a number of fragmentary ivory small-scale sculptures that served as components of the luxurious decoration of chryselephantine couches from ancient Macedonia. The ivory fragments come from funerary contexts (the tomb of Philip II at Aigai, the Macedonian tomb II of Korinos at Pydna and the Macedonian tomb III of Aghios Athanassios near Thessaloniki), all of which are dated to the last quarter of the fourth century BC. The use of bright pigments on the laboriously executed faces of the figures and their garments, together with the gold leaf applied onto the hair and the background, conveys a powerful effect of polychromy that would have immediately caught the spectator's eye, enhancing the overall aesthetic and material value of such lavishly decorated furniture. The identification of the pigments and the techniques of their application have been studied with the use of analytical methods (XRF, micro-XRF, XRD and SEM-EDS) and multi spectral imaging (Visible Induced Luminescence).

Keywords. Ivory polychromy, chryselephantine couches, Hellenistic period, cinnabar, Egyptian blue, lead white, kaolinite, gilding, Aigai, Pydna, Aghios Athanassios, tomb of Philip II, micro-XRF, XRD, SEM-EDS, VIL.
\end{abstract}

Résumé. Le présent article est consacré aux traces de polychromie retrouvées sur un certain nombre de sculptures fragmentaires en ivoire de petit format composant la somptueuse décoration des lits de banquets chryséléphantins de la Macédoine antique. Ces fragments en ivoire ont été découverts dans des sépultures (la tombe de Philippe II à Aigai, la tombe macédonienne II de Korinos à Pydna et la tombe III d'Aghios Athanassios près de Thessalonique, toutes datées du dernier quart du IV siècle avant Jésus-Christ. L'utilisation de pigments éclatants sur les visages soigneusement travaillés des figurines ainsi que sur leurs vêtements, tout comme la feuille d'or, appliquée sur la chevelure et sur le fond, leur confèrent une puissance de chatoiement qui devait immédiatement frapper le spectateur, renforçant l'impression esthétique comme la valeur matérielle de ce mobilier si fastueusement décoré.

Lidentification des pigments et les techniques de mise en cuvre employées ont été étudiées à l'aide d'analyses en XRF, micro-XRF, $D R X, M E B-E D S$ et de l'imagerie multi-spectrale (photoluminescence)

Mots-clés. Ivoire polychrome, lits de banquets chryséléphantins, période hellénistique, cinabre, bleu égyptien, blanc d'argent, kaolinite, dorure, Aigai, Pydna, Aghios Athanassios, tombe de Philippe II, micro-XRF, DRX, MEB-EDS, LIR.

gold decorations of funerary couches in Macedonia - including glass elements ${ }^{3}$, plaques with figures shaped in golden foils underneath, and rich polychromy - come from the royal tombs II and III at Aigai ${ }^{4}$, the so-called tomb of the Palmettes at Mieza ${ }^{5}$ and the tomb II of Korinos, south of Pydna ${ }^{6}$. A small number of fragments has survived from the couch of the more recently discovered tomb III at Aghios Athanassios, near Thessaloniki ${ }^{7}$. Exceptional, in terms of their artistic quality and good preservation, are the multi-figure chryselephantine compositions on the wooden frames of the two couches deposited in the antechamber and the main chamber of the tomb of Philip II (fig. 1). It has been suggested that such elaborate couches were not created ad hoc to accompany

Hariclia Brecoulaki, Researcher-Archaeologist, Institute of Historical Research, The National Hellenic Research Foundation, Athens (hbrek@eie.gr). Sophia Sotiropoulou, Research Scientist, The Ormylia Art Diagnosis Centre, Chalkidiki (s.sotiropoulou@artdiagnosis.gr). Christos Katsifas, Chemist, The Archaeological Museum of Thessaloniki (chris.kats@yahoo.com). Andreas G. Karydas, Research Scientist, International Atomic Energy Agency, Nuclear Science and Instrumentation Laboratory, A-2444 Seibersdorf, Austria (A.Karydas@iaea.org). Vicky Kantarelou, Research Scientist, Institute of Nuclear Physics, NCSR DEMOKRITOS, Athens (kantarelou@inp.demokritos.gr).

Funerary bed-couches (klinai), made of stone or wood and deceased or to receive the larnakes with their ashes, in the case of cremations ${ }^{1}$. The choice of the material used for the couches found in Macedonian tombs are made of stone, chryselephantine couches were reserved for the burials of wealthy individuals. The best preserved examples of ivory and 
the deceased in their after-life, but rather that they were part of the luxurious furniture that kings and élite members of the local society used in real life ${ }^{8}$.

\section{Chryselephantine statuary and the Macedonian court}

Chryselephantine statuary, combining the use of gold and other precious or semi precious materials (inlays of coloured stones, metals, glass and amber), has been considered as the most expensive and highest form of artistic production in Classical antiquity ${ }^{9}$. The effect of luminosity emanated by the polished surface of ivory, together with the shine of gold and the vividness of precious pigments, produced an overall effect of splendor, associated with divine epiphany ${ }^{10}$. The most famous statues of the Classical world, such as the huge statue of Athena and Zeus Olympios created by Pheidias ${ }^{11}$, were fashioned in ivory. Precious ivory had already been imported into Greece from the East since the Bronze Age ${ }^{12}$. Its physical properties - in terms of texture, hardness and colour - made it an ideal material for accurate curving, offering ancient sculptors advanced possibilities of achieving realistic effects ${ }^{13}$. Its warm and creamy hue was often imitated by the whitish colour and luminous surface of Parian or Pentelic marble, in both furniture and other luxurious artifacts (as for example the marble pyxides of the late fifth century BC from Attica ${ }^{14}$ and the Cyclades ${ }^{15}$, or the marble throne in the "tomb of Eurydice" at Aigai ${ }^{16}$ ). The creamy hue of the painted funerary couch from the Macedonian tomb of Potidea was certainly a direct allusion to the colour of ivory, successfully imitated by the painter with thick layers of lead white mixed with yellow ochre ${ }^{17}$. Considering the high price of elephant tusks, ivory was usually used for the nude parts of the figures and faces, while the rest was made of wood and stucco, decorated on the surface with gold leaf and various pigments. This technique seems to have been adopted for the production of most composite ivory statues. Pausanias reports that the statues of Athena at the sanctuary of Zeus at Megara and at Aigeira, had their exposed parts - hands, feet and face - made of ivory, while the draperies and hair were made of gilded wood with applied polychromy (1.42.4; 7.26.4) ${ }^{18}$. Although textual sources confirm the colouring of ancient ivory statuary, physical remains of pigments are scarce, mainly due to their poor preservation and/or the burning of the original ivory surfaces. In fact, most of chryselephantine statuary from Antiquity has disappeared due to the high value of its constituent materials and to the fragility of the composite technique and the perishable materials of organic origin used to produce them ${ }^{19}$.

Despite their small scale, the ivory figures that originally decorated luxurious Macedonian couches - either attached as appliqués on gilded backgrounds, or in high relief, almost carved in the round ${ }^{20}$ - represent the most direct evidence of the remarkable artistic quality that chryselephantine statuary had reached during the Hellenistic period. The decoration of Macedonian couches with ivory reliefs of very high quality certainly reflects the preference of the Macedonian élite for this precious material. Pausanias reports the dedication of ivory statues of the royal family by Philip II and Alexander at the Philippeion at Olympia and attributes them to the famous sculptor Leochares (5.20.9-10) ${ }^{21}$. Following the example of Philip and Alexander, Hellenistic monarchs, who had easier access to ivory supply ${ }^{22}$, continued the tradition of ornamental ivory carving for their sumptuous furniture (Ath., 5.205c) and kept ordering remarkable free-standing chryselephantine statues to decorate their luxurious pavilions and barges ${ }^{23}$.

\section{A technological examination of the polychromy applied on three Macedonian couches}

The fragments of ivory decorations with traces of polychromy and gilding examined in this paper were originally part of three funerary couches discovered inside the tombs of Philip II at Aigai (kline of the main chamber), the Macedonian tomb of Korinos (Tumulus II) and the tomb III of Aghios Athanassios. The technological examination of the paint layers preserved on the couches' fragments allowed us to reconstruct the original gamut of pigments and the techniques of their application, reflecting the major role of colour and painting in the completion of such composite and refined artifacts. A highly pictorial use of colour is documented in the rendering of the figures' facial features, together with a predilection for precious and bright pigments for the polychromy of the garments. Notwithstanding the fragmentary condition of the chryselephantine couches and the poor state of their preservation (in most cases eroded), the surviving evidence offers different, yet complementary, aspects of polychromy. While in the tomb of Aigai, colours and gilding are best preserved on the background and the area of the garments originally made of wood and stucco, in the tomb of Korinos and of Aghios Athanassios, extremely well-preserved paint layers are visible on the figures' and griffins' faces; paint layers that had been directly applied on the polished surface of ivory. We therefore have evidence of the use of colour on both the nude parts made of ivory and on the clothed parts, originally made of wood and stucco.

\section{The funerary couch in the main chamber of the tomb of Philip II at Aigai}

The exceptional quality of the overall decoration of this couch makes it a true masterpiece of ancient art (fig. 1). The couch was decorated with ivory, gold and glass only on the front, the back and sides were filled with gilded reliefs and ornamental painted motifs directly on wood (of which some evidence is still preserved today) ${ }^{24}$. Tiles, ivory reliefs, inlays of glass and gold were used for the decoration of the legs, and low reliefs in ivory were fixed to the upper cross-bar of the couch. On the wide frieze directly below, a gilded panel served 


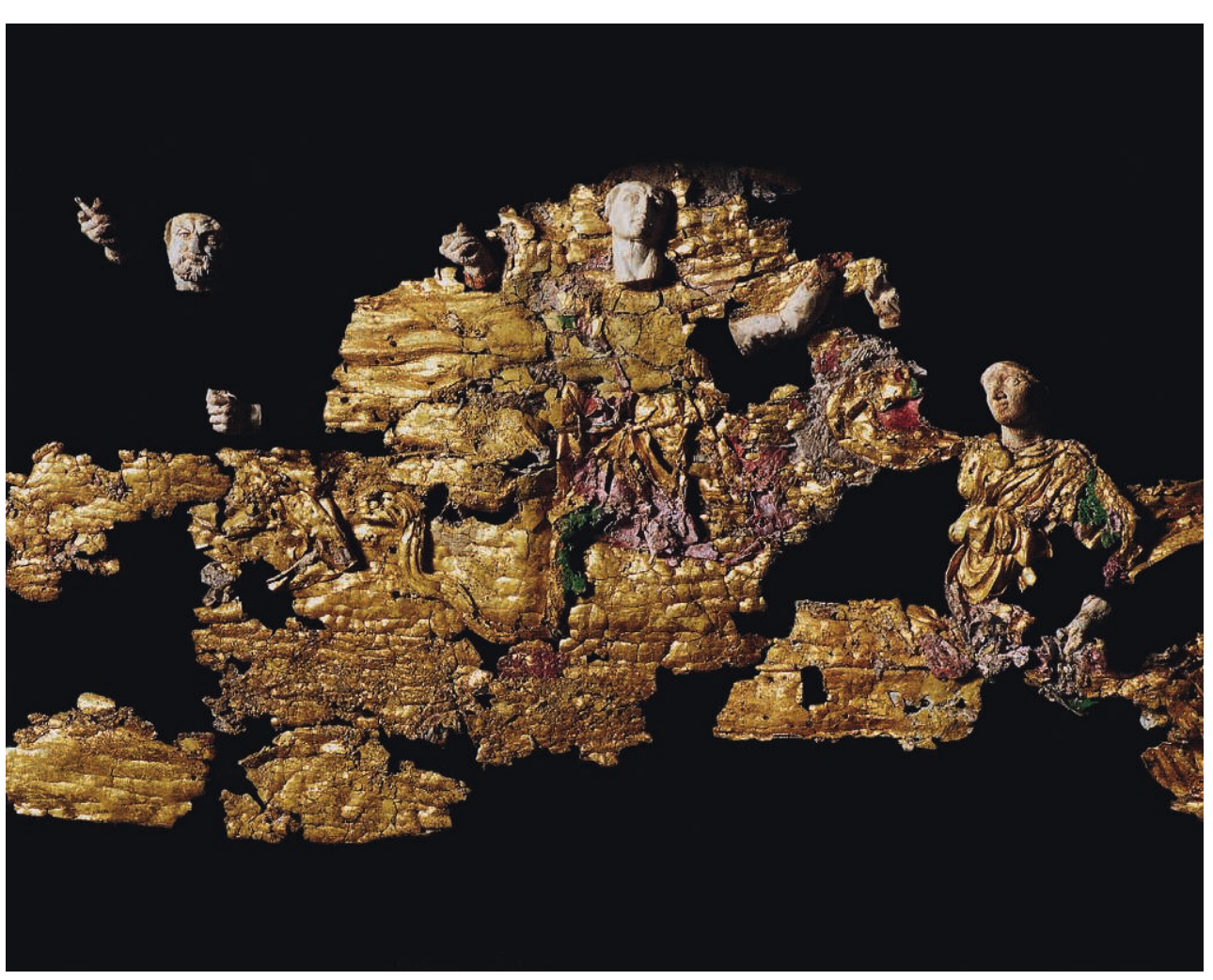

Fig. 2. Aigai, Museum of the Royal Tombs. Chryselephantine couch from the burial chamber of the tomb of Philip II, detail (Kottaridi 2013, p. 301). (c) $17^{\text {th }}$ Ephorate of

Prehistoric and Classical Antiquities.

as the background for a multi-figure hunting scene, comprising at least fourteen male figures on foot and on horseback, rendered in fairly high relief. The hunters were wearing short tunics, cloaks, boots and the typical Macedonian hat, the kausia. Despite their small scale, each one of the faces (ten of which are well preserved) is rendered with individualized features and marked expressions, as if they were true portraits ${ }^{25}$. Although a large number of figures is preserved, almost no trace of the original polychromy on the ivory parts survives. The paint layers and gilding that did not vanish were originally applied to the clothed parts of the figures - to indicate the folds of the garments and other details - and on the panel background, serving as a golden field surrounding the participants of the royal hunt with warm light. Traces of saturated hues of red, green, blue, pink and purple are preserved (fig. 2), but often pigments seem to have migrated from their original areas of application.

\section{Technical apparatus and methodology}

A first analytical investigation was performed on a subset of six samples taken from detached fragments from the background and the wooden parts of the composition, recovered with stucco and bright pigments, mainly corresponding to the area of the garments. The results of this investigation were published in 2006, together with the technological examination of the painted hunting scene of the tomb's façade ${ }^{26}$. The samples were examined under a stereomicroscope and were then mounted into resin and analyzed with scanning electron microscopy with energy dispersive X-ray spectrometry (SEM-EDX) ${ }^{27}$. The green pigment, identified as a rare copper based mineral, was also examined by means of X-Ray diffraction. A subsequent wider non-destructive analytical investigation in situ and at the laboratory ${ }^{28}$ was carried out in 2013 (see results in table 1, fig. 19), in order to clarify issues mainly related to the chemical composition of the green and black pigments, as well as to map the extent of their use. A handheld XRF analyzer (Niton XL3t, GOLDD+) ${ }^{29}$ was utilized during the in situ measurements at the Laboratory of the museum of the Royal Tombs at Aigai and scanning micro-XRF analyses were performed on a few samples by means of a customized version of the Artax commercial portable micro-XRF spectrometer (Bruker Nano Analytics) ${ }^{30}$.

\section{Materials and techniques}

The pigments identified - except for the green and a black associated with it - correspond to well-known materials that ancient painters used both in painting and sculpture: cinnabar, Egyptian blue, yellow ochre, kaolinite, calcite and an organic purple probably deriving from Murex ${ }^{31}$. The coloured pigments were usually applied over an undercoat of kaolinite mixed with calcite, which corresponded to the original gesso layer of a variable thickness between 300 and $350 \mu \mathrm{m}$, applied over the wooden parts of the figures and the background ${ }^{32}$. Cinnabar was used for the red saturated hues, and a mixture of cinnabar with calcite and kaolinite produced pinkish hues. The use of cinnabar - the brightest and most precious mineral 


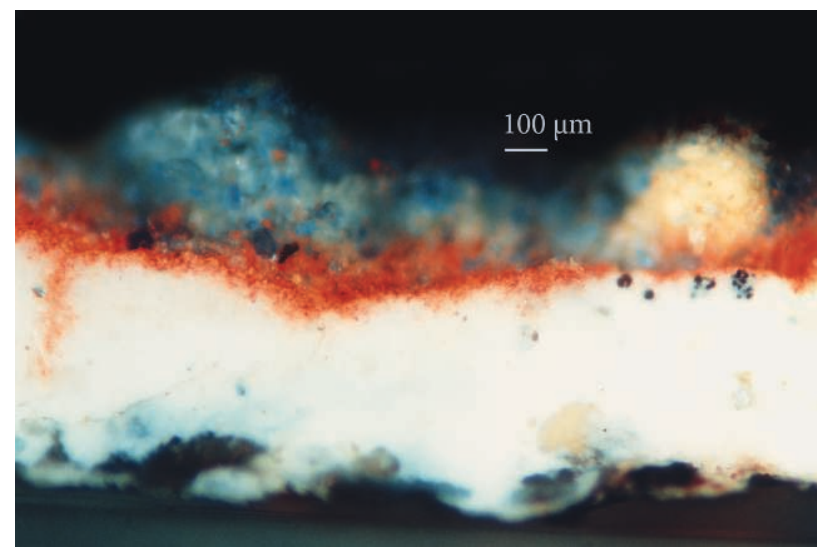

Fig. 3. Aigai, Museum of the Royal Tombs.

Chryselephantine couch from the burial chamber of the tomb of Philip II. Photomicrograph of paint cross section in reflected light. The sample is

composed of a bottom layer of kaolinite; a second layer of cinnabar and a top layer of Egyptian blue. (c) H. Brecoulaki.

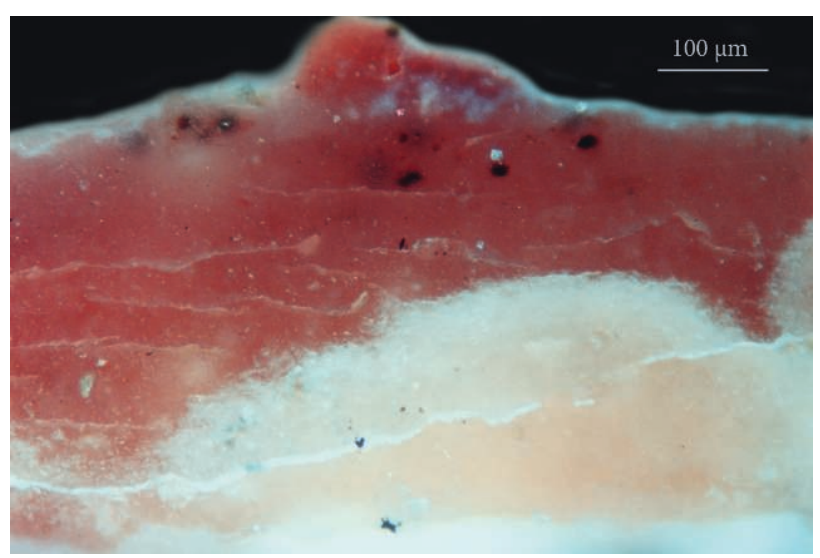

Fig. 4. Aigai, Museum of the Royal Tombs.

Chryselephantine couch from the burial chamber of the tomb of Philip II. Photomicrograph of paint cross section in reflected light. The sample is composed of an undercoat of lead white/calcite on top of which is applied a purple paint of organic origin, probably deriving from Murex purple. () H. Brecoulaki. red of antiquity ${ }^{33}$ - has been amply documented on funerary Macedonian painted monuments and this represented a particularly favored hue of the local palette. It is probable that cinnabar was procured by nearby mineral sources ${ }^{34}$, a fact that would explain its constant high quality and widespread application. Egyptian blue was applied pure, in homogeneous layers directly on the gesso or superimposed onto other paint layers (in sample KLF7 Egyptian blue is applied over a layer of cinnabar (fig. 3). A light purple paint layer of organic origin with grains of hematite was superimposed onto an undercoat of kaolinite, and a darker purple layer (probably deriving from Murex) ${ }^{35}$ was applied to a layer composed of lead white and calcite (fig. 4). The use of lead white as an undercoat to organic pigments has been attested in several occasions on funerary paintings from Macedonia and it seems to have served practical requirements: to create a compact and nonporous layer that would enhance the luminosity and the adhesion of the semi-transparent organic pigment or lake ${ }^{36}$. The use of Murex purple has been attested in Macedonian paintings of the late fourth century $\mathrm{BC}^{37}$, although, in most cases, its cheaper substitute, Madder-lake, was preferred. The cross section of a sample taken from the background of the hunting scene, allowed us to reconstruct the stages of the gilding technique (fig. 5): onto a first layer of stucco composed of kaolinite and calcite, a thick layer of yellow ochre is applied, serving as a coloured undercoat. The gold leaf, a few microns thick (2 to 3 ), is attached to the ground of yellow ochre by means of an organic adhesive, visible in the cross section as a semi transparent layer of 20-30 $\mu \mathrm{m}$ thickness. It is probably composed of vegetable gums, as their use has been widely attested in Macedonian painting ${ }^{38}$. The gold leaves were subsequently burnished to create a homogeneous and shiny surface. This technique, known as the "bole technique" (Pliny, NH 35.133), including grounds of yellow or red ochres, represents a common artistic background and went on to be practiced throughout Antiquity, until modern times. It has been scientifically documented on Hellenistic Delian sculptures and terracottas ${ }^{39}$, and traces of gilding on wood are still preserved on fragmentary pieces of sarcophagi and statuettes from Kertch ${ }^{40}$.

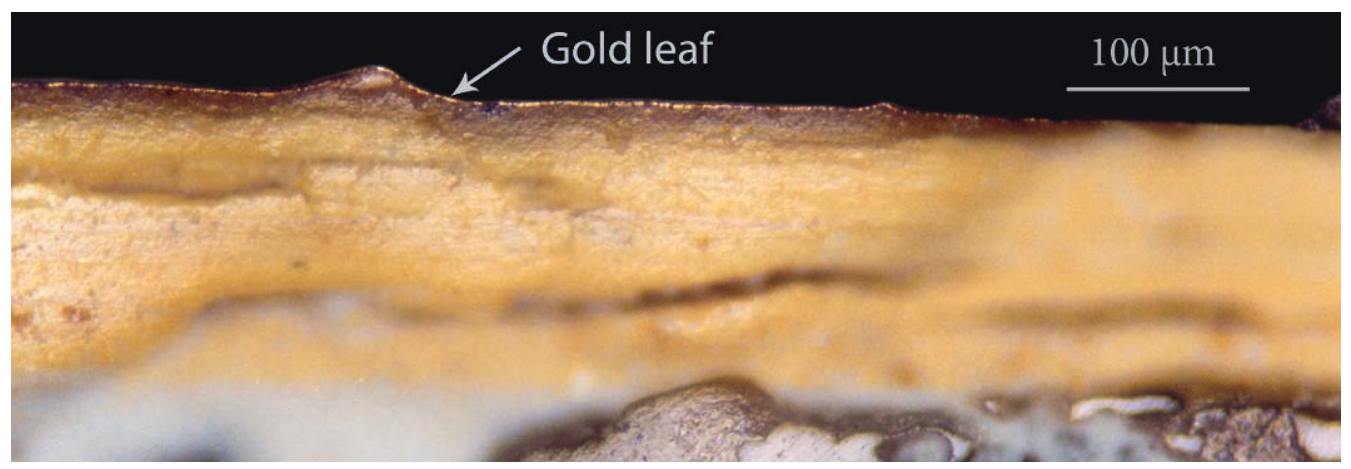

Fig. 5. Aigai, Museum of the Royal Tombs. Chryselephantine couch from the burial chamber of the tomb of Philip II. Photomicrograph of paint cross section in reflected light. In the sample are visible four distinct layer: a white layer of kaolinite/calcite; a layer of yellow ochre; a thin semitransparent layer of an organic binder and a gold leaf. (c) H. Brecoulaki. 


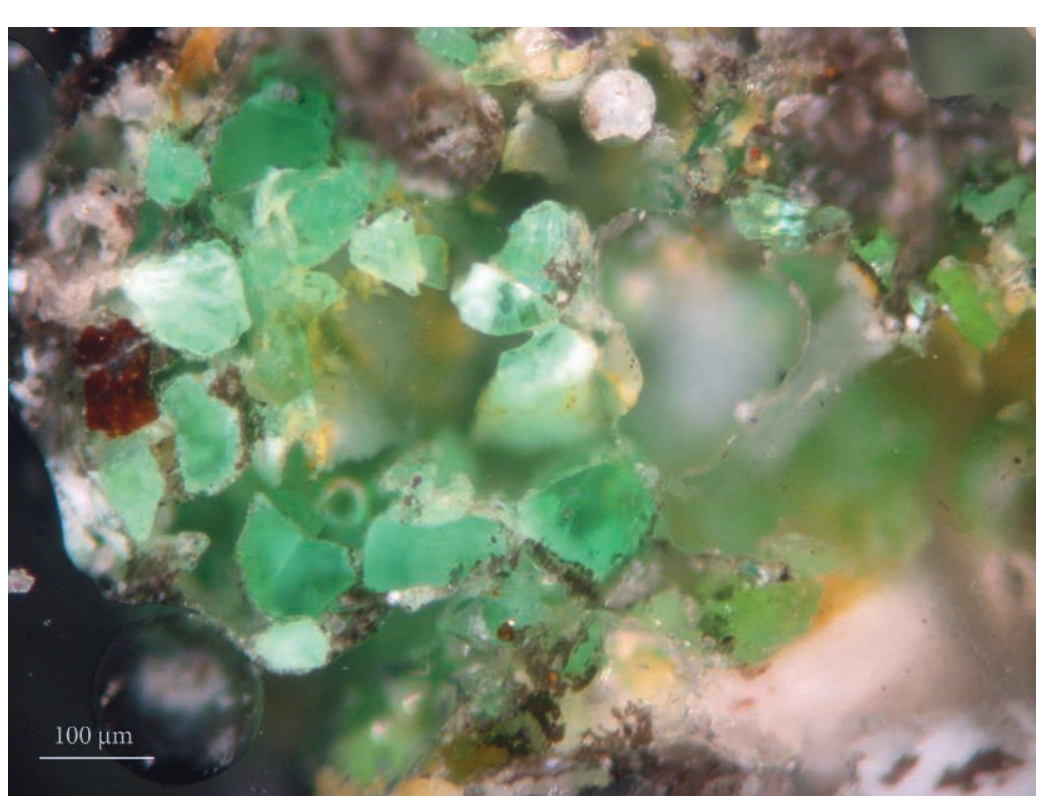

Fig. 6. Aigai, Museum of the Royal Tombs.

Chryselephantine couch from the burial chamber

of the tomb of Philip II.

Photomicrograph of

paint cross section in

reflected light. The

sample is composed of

conichalcite.

(c) H. Brecoulaki.

\section{The case of conichalcite, an unusual green pigment}

The vivid green pigment that is still visible on various parts of the figures' garments (fig. 2) was identified as the mineral conichalcite and this is the first documented use of this mineral as a painting material ${ }^{41}$. What makes this mineral attractive in terms of an artistic use is the luminous and intense apple-green colour of its grains (fig. 6). Conichalcite is a copper arsenate mineral, generally found among surface alteration products, encrusted on to limonitic rocks that have yellow to red colours. It is often associated with other copper based minerals such as azurite and malachite ${ }^{42}$. In samples KLF2 and KLF5, the results of the handheld XRF and microXRF analyses (Table 1, fig. 19) indicate the presence of the major constituents of conichalcite - As and $\mathrm{Cu}$ - often in association with $\mathrm{Pb}$. In the case of the fragment KLF5 (fig. 7a), the surface shows a green and black colored area with the latter serving as substrate of the top green layer. The microXRF scanning analyses (fig. $7 \mathrm{~b}^{43}$ ) show that the As and $\mathrm{Cu}$ are perfectly spatially and intensity-correlated in the red (pseudo-coloured area) corresponding to the green paint (fig. 7 a), as both elements are constituents of the mineral conichalcite. In both green and black areas the inhomogeneous major presence of $\mathrm{Pb}$ is recorded. However, the composition of the black undercoat, on which $\mathrm{Cu}$ and $\mathrm{Pb}$ were majorly detected, was not clarified, thus requires further investigation.

In the case of KLF2, As and Cu are also perfectly correlated, whereas lead is detected in rather trace amounts.

These micro-XRF findings are in agreement with the results of the handheld XRF analyses as far as the green $(\# 1,24,11)$ and black areas $(\# 3,7,8,10)$ are concerned. Conichalcite

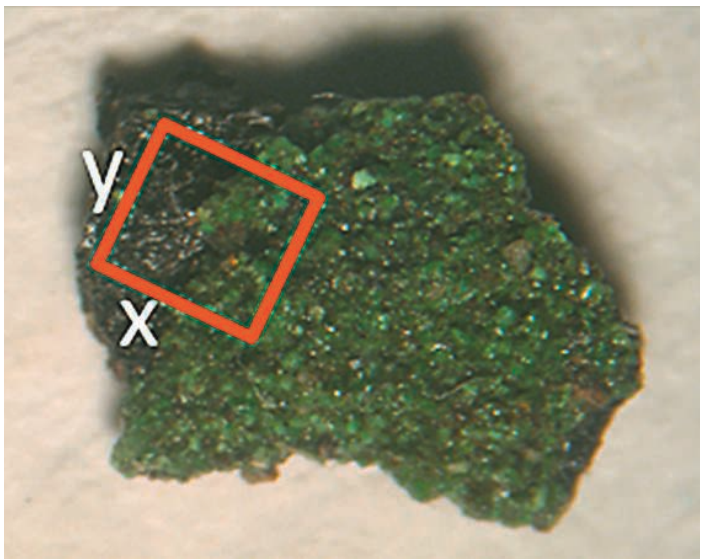

Fig. 7 a. A photo of the fragment KLF5 is depicting a top surface green paint layer, whereas, at the left side, a black colored substrate is revealed. (C) Andreas Karydas.

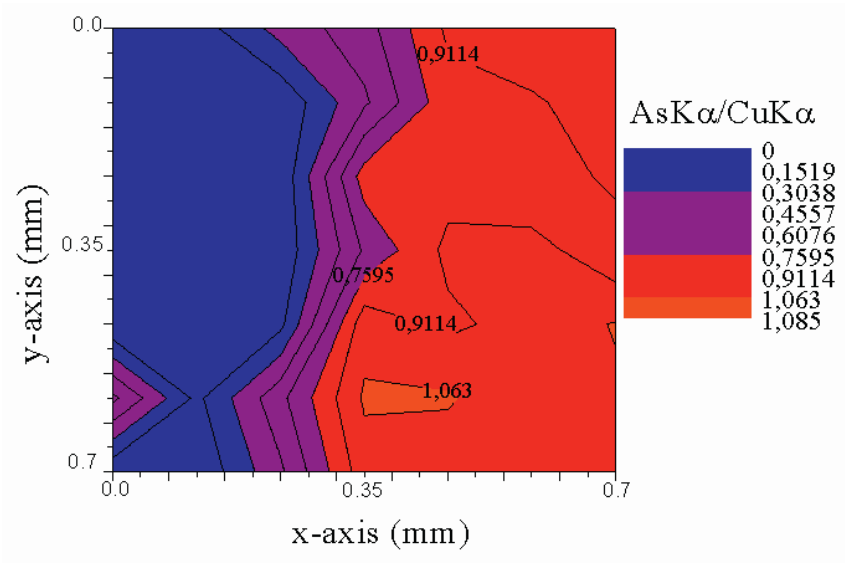

Fig. 7 b. Quantitative spatial distribution of the As-Ka to $\mathrm{Cu}-\mathrm{K} \alpha$ characteristic X-ray intensities, as they were deduced by means of a micro-XRF scan on the sample KLF5 surface. As is present only in the green colored area, whereas $\mathrm{Cu}$ is contained in both the green top laver and in the black substrate. In the green colored area the ratio of As to $\mathrm{Cu} \mathrm{K \alpha}$ elemental intensities is very close to 1 resembling the expected intensity ratio according to the weight fraction of the two elements in conichalcite compound. (c) Andreas Karydas. 
$\left(\mathrm{CaCu}\left[\mathrm{AsO}_{4}\right][\mathrm{OH}]\right)$ belongs to the adelite group of minerals, a series of orthorhombic arsenates and vanadates. A wide variety of substitutions may occur, thus giving a general formula for this group $\mathrm{AB}^{2+}\left({ }_{\mathrm{X}} \mathrm{O} 4\right)(\mathrm{OH})$, where $\mathrm{A}$ is calcium or lead, B is cobalt, copper, iron magnesium, nickel or zinc, and $\mathrm{X}$ is either arsenic or vanadium. Microprobe analyses and $\mathrm{X}$-ray powder-diffraction studies have indicated that extensive $\mathrm{Cu}-\mathrm{Zn}$ and $\mathrm{Pb}-\mathrm{Ca}$ substitutions may occur, which represent solid solutions among conichalcite, austenite and duftite, all minerals of the adelite group of arsenates ${ }^{44}$.

Conichalcite has been detected in association with the green pigment malachite, in funerary paintings of the fourth and third centuries BC in Macedonia and Thessaly. Its occurrence on Macedonian paintings suggests it was of local provenance, probably accessible from the nearby copper deposits on the Chalcidice peninsula. However, what is noteworthy in the application of conichalcite onto the Aigai couch is the particularly coarse size of its grains, which produces a luminous and saturated effect (fig. 6). The use of such pure and non-grinded conichalcite has not been attested on any other monument, thus far. Conichalcite was applied either directly onto the stucco layer, or on top of a thick black copper based layer (possibly a copper oxide black), serving as an undercoat. Pliny the Elder reports a similar technique and advises painters to use a layer of carbon black before they apply chrysocolla (corresponding to malachite), in order to strengthen the colour of the latter ( $N H$ 33.91). Grains of goethite detected together with conichalcite perhaps suggest an intentional mixture aimed at to enhancing the colour's luminosity, or a contamination from the limonitic rocks, where conichalcite is often encrusted (fig. 8).

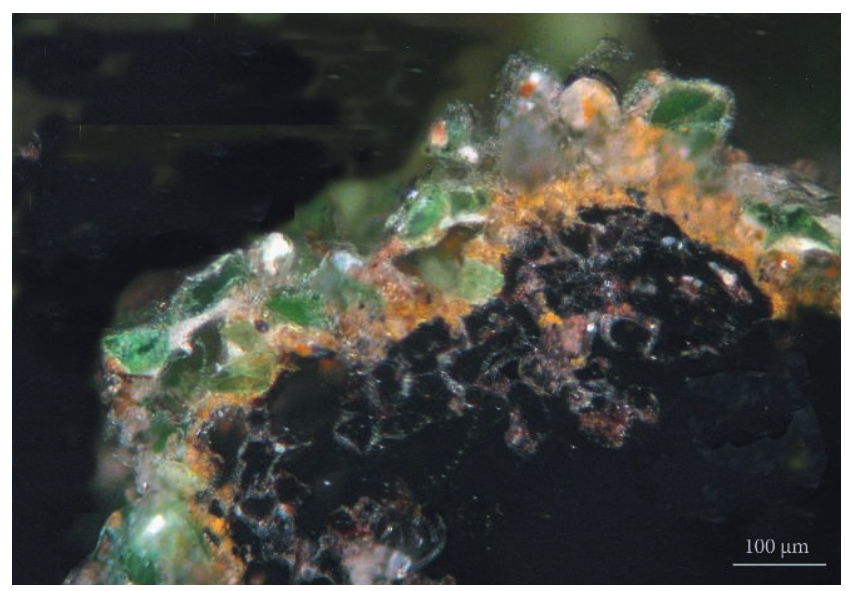

Fig. 8. Aigai, Museum of the Royal Tombs. Chryselephantine couch from the burial chamber of the tomb of Philip II. Photomicrograph of paint cross section in reflected light. The sample is composed of a bottom layer of black paint (copper based); a second thin layer of yellow ochre and a top layer of conichalcite. (C) H. Brecoulaki.
Conichalcite was recently also identified on the wall painting with the hunting scene on the façade of the tomb of Philip II at Aigai ${ }^{45}$, attesting to the preference for this material by local artists. However, it is interesting to observe the different, more pictorial, application of conichalcite in the figural painting of the tomb. While on the couch, conichalcite is applied pure, in very coarse grain size, so that its brightness and saturated colour would be privileged, in the wall painting, conichalcite is finely grinded and always used in intermixtures with other pigments. In fact, the painter of the hunting scene chose the green pigment to create the cool shadows for the receding parts of the hunters' bodies, thus announcing a first application of the so-called verdaccio technique, that would go on to be fully developed in later times by Medieval and primitive Italian painters for the rendering of the skin tones ${ }^{46}$.

The pigments used to indicate drapery on the Aigai couch are applied in pure, thick layers, and intermixtures are attested only for the production of pinkish hues. The aesthetic effect produced by the bright polychromy and pure gold leaves applied onto the wooden parts of the couch would have immediately grasped the attention of spectators entering the royal andron, reflecting through its splendor the high social status of its owner. In fact, the choice of the painting materials was in accordance with the overall high material value of the prestigious artifact. The nude parts of the figures' bodies and faces, deprived today of their original paint layers, seem too "white" compared to the rich polychromy of their garments. Nonetheless, the excellent preservation of colour on the ivory faces from the tomb of Pydna presented here below allows us to imagine the way in which painters would have combined the saturated tones of bright garments with a more pictorial application of colour for the rendering of the facial features.

\section{Ivory figures from the couches of the Macedonian tombs at Korinos and Aghios Athanassios}

A large number of ivory inlays with incised figurative motifs and members of small-scale human figures in high relief were found in the Macedonian tomb II at Korinos, dated to the end of the fourth century $\mathrm{BC}^{47}$. The ivory decorations originally served as components of a wooden couch placed in the burial chamber of the tomb. A total of twelve heads and around sixty fragments belonging to upper and lower members of carved bodies (mainly composed of feet, legs, arms and hands with five pieces belonging to male torsos) were part of a composition depicting a battle scene between Greeks and Persians, on the wide frieze between the two kanons of the couch $^{48}$. Each face is rendered with personalized features and intense expressions achieved by the deep carving of the eyes, the indication of wrinkles on the front and the antithetic movement of the neck (figs 9-11). Circular mortises made with drills, into which dowels and pins for assembly were originally inserted, are visible on the bottom part of the neck. 


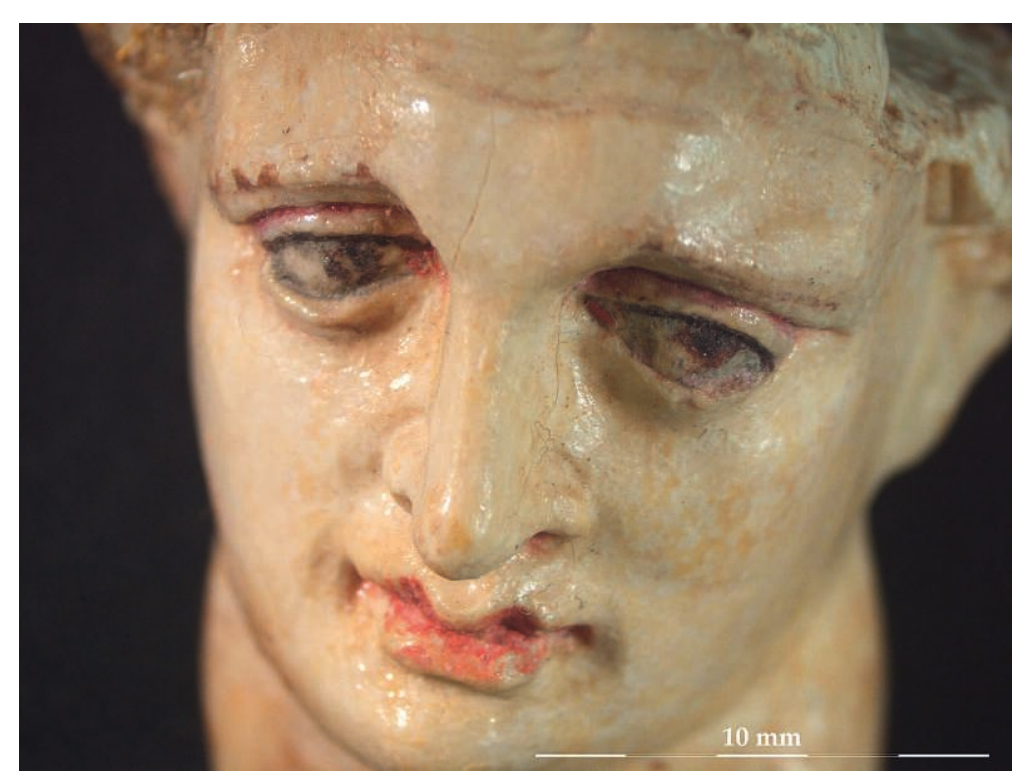

Fig. 9. Korinos, Tomb II.

Chryselephantine couch.

Photomicrograph of the

ivory male head Пu 4374

taken by $\mathrm{H}$. Brecoulaki.

(C) $16^{\text {th }}$ Ephorate of

Prehistoric and Classical

Antiquities.

Fig. 10. Korinos, Tomb II.

Chryselephantine couch.

VIL photograph of the

ivory female head

Пu 4375, taken by

S. Sotiropoulou.

(C) $16^{\text {th }}$ Ephorate of

Prehistoric and Classical

Antiquities.
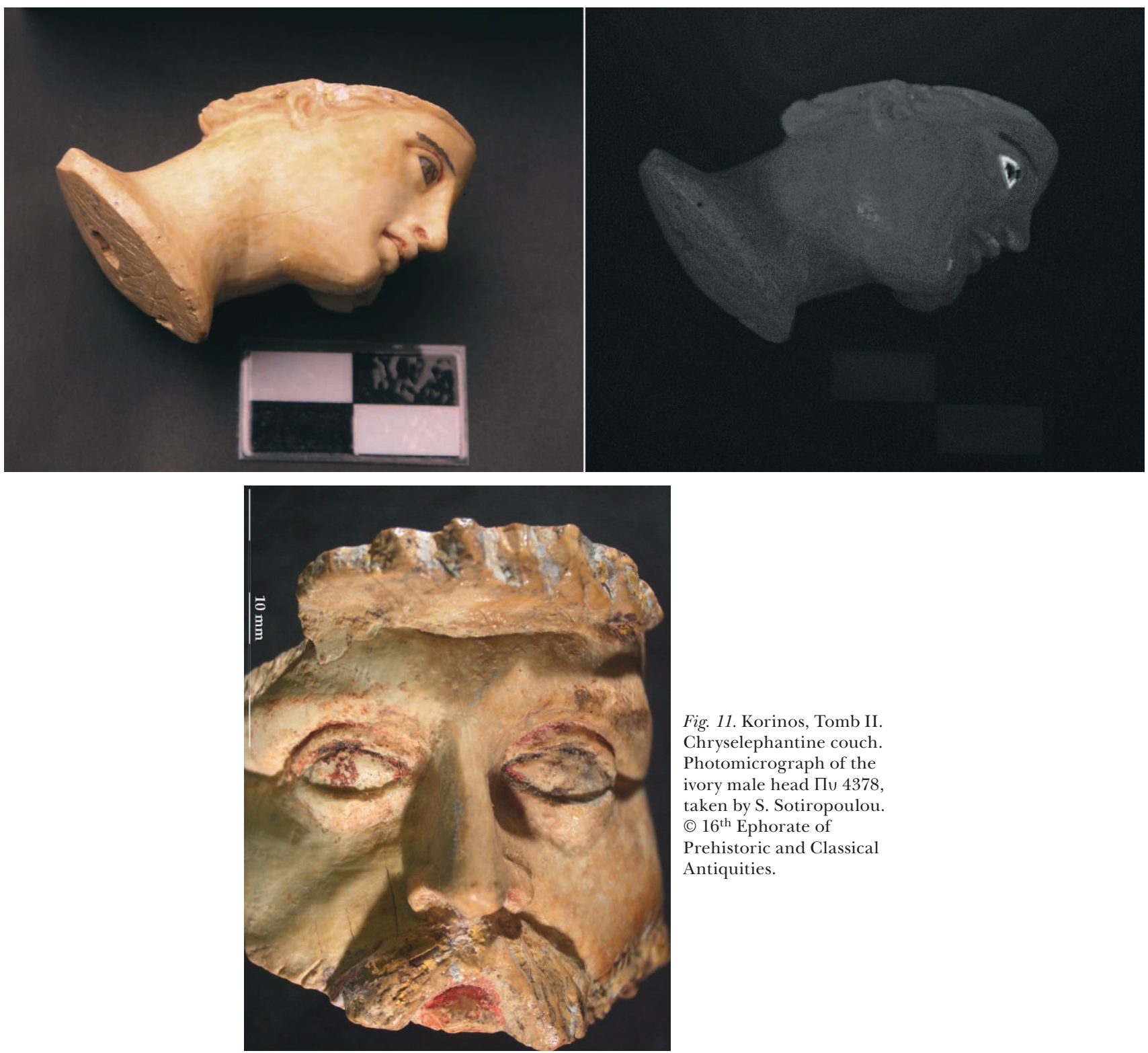

Fig. 11. Korinos, Tomb II.

Chryselephantine couch.

Photomicrograph of the

ivory male head Пu 4378 ,

taken by S. Sotiropoulou.

(c) $16^{\text {th }}$ Ephorate of

Prehistoric and Classical

Antiquities. 
The final surface of the fragments is properly polished, preserving the original warm hue of ivory in the areas of the bodies intentionally left white. Two more fragments of ivory depicting griffin heads, preserving their original polychromy in a remarkably good state, were components of the fragmentary wooden couch found in the burial chamber of the Macedonian tomb III at Aghios Athanassios (near Thessaloniki), dated to the last quarter of the fourth century $\mathrm{BC}^{49}$ (figs 12-13). The fragments were collected together with more inlaid ivory figures - badly worn -, and at least eighteen glass plaques with silver-coated figures from the decoration of the couch.

16

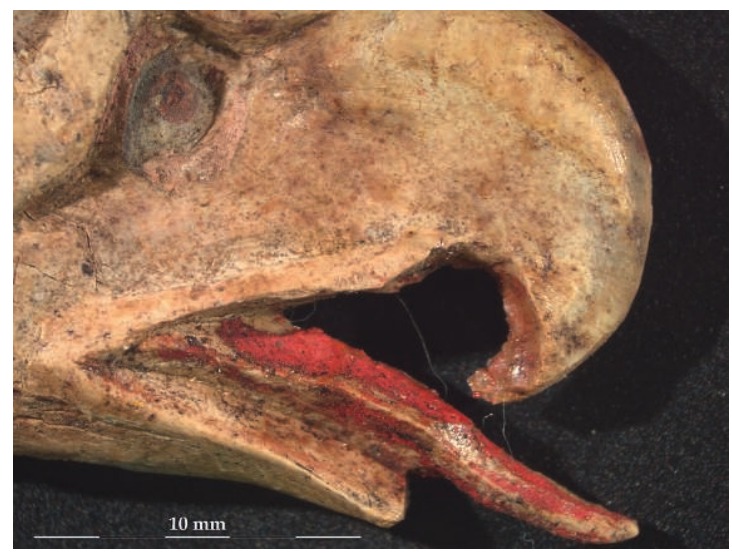

Fig. 12. Aghios Athanassios, Tomb III. Chryselephantine couch. Photomicrograph of the ivory griffin's head 19429a, taken by S. Sotiropoulou. (c) $16^{\text {th }}$ Ephorate of Prehistoric and Classical Antiquities.

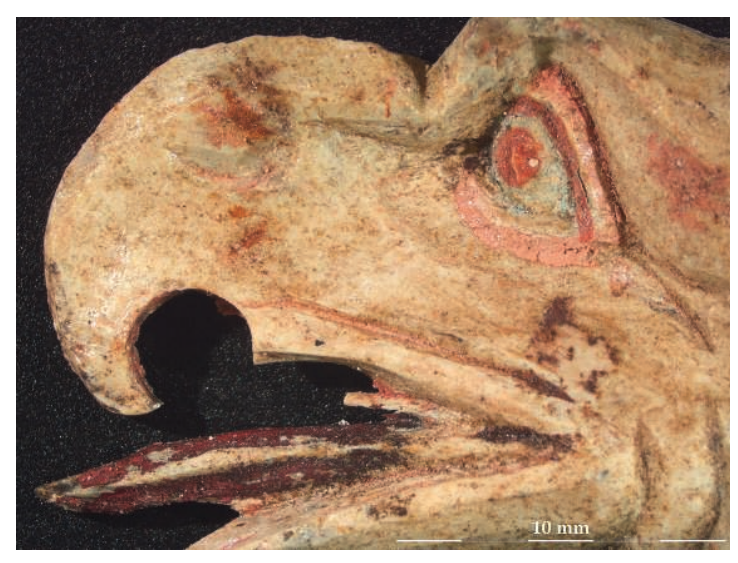

Fig. 13. Aghios Athanassios, Tomb III. Chryselephantine couch. Photomicrograph of the ivory griffin's head 19429b, taken by S. Sotiropoulou. (c) $16^{\text {th }}$ Ephorate of Prehistoric and Classical Antiquities.

\section{Technical apparatus and methodology}

Two male and one female miniature heads from the tomb of Korinos (Пv 4374, Пv 4375, Пv 4378) and two griffin heads from the tomb of Aghios Athanassios (19429a, 19429b) were examined visually and photographed under a Zeiss Stemi 2000-C stereomicroscope. For the study of the fine paint layers of the ivory figures energy dispersive X-ray Fluorescence measurements were conducted at the laboratory of the Archaeological Museum of Thessaloniki, where the fragments are actually stored. An Artax 400 mobile spectrometer ${ }^{50}$, especially designed for the demands of Archaeometry ${ }^{51}$ (see table II, fig. 20), was used. An effort to obtain complementary information on the composition of the pigments through microRaman measurements, which would allow us to refine the elemental analysis data, was not successful due to the high fluorescence of both the substrate and the synthetic resin (most probably acrylic) that was used for the consolidation of the remaining paint. The Visible Induced Luminescence imaging method was applied to detect and to map Egyptian blue on the paint decoration of the objects. This method ${ }^{52}$ is based on Egyptian blue cuprorivaite's property of emitting infrared luminescence when excited in the visible area. Since its first application, the conditions of excitation and acquisition were progressively improved by taking into consideration the spectroscopic behavior of the material ${ }^{53}$. This exceptional property of Egyptian blue allows it to be distinguished from all other natural or synthetic blue pigments that are not photoluminescent in the spectral range under study ${ }^{54}$.

\section{Materials and techniques}

Despite the small-scale of the fragments, a large amount of technical information was obtained, allowing us to reconstruct important aspects of sculptural polychromy and to obtain a unique insight into the pictorial use of colour on ancient Greek ivory statuary. Delicate paint layers were applied to accentuate the different features of the faces, carved with extreme craftsmanship, and to revive the expression of the gaze. On the three human faces from Korinos (Пv 4374, Пv 4375, Пv 4378), bright cinnabar was used to paint the lips ${ }^{55}$ and the nostrils of the nose. A remarkably detailed treatment is observed on the different parts of the eyes, in the painter's attempt to create a more realistic appearance of the human faces. On the male head Пv 4374 (fig. 14), the pupil of the eye is painted in dark brown, composed of an iron based ochre with some grains of cinnabar, and the iris in a lighter hue of brown. The lacrimal duct is indicated with a round brush stroke of cinnabar and the same hue was used for the shadow on the upper eyelids. The lower eyelids preserve traces of a pinkish cool layer, probably deriving from the mixture of a pigment of organic origin (not identified) with Egyptian blue (visible in the VIL image). Traces of brown are preserved in the area of the eyebrows. A similar polychromy has been applied onto the eyes of the second male head 


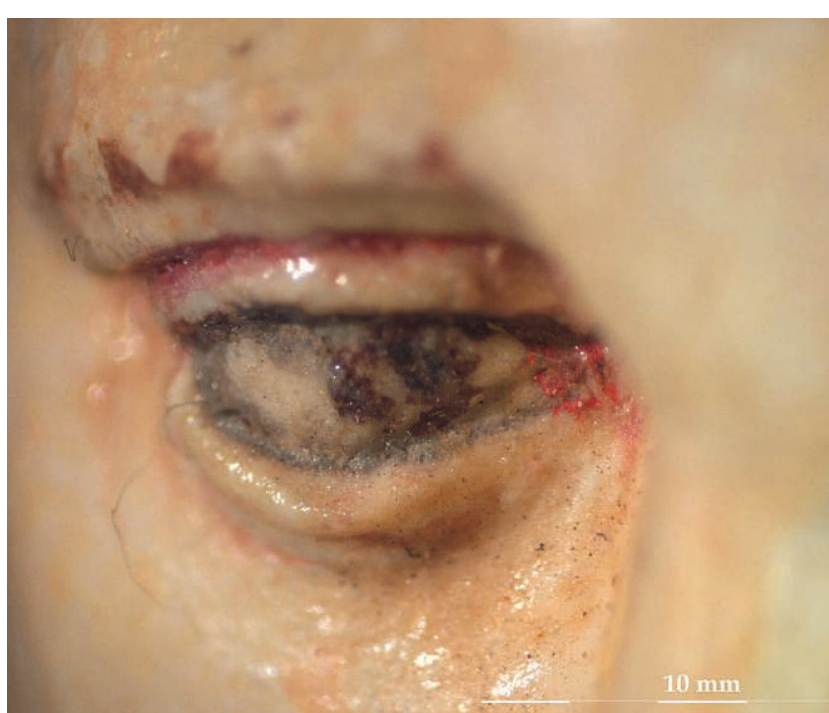

Пv 4378 (fig. 11). The iris and pupil of the eye of the female figure Пu 4375 (fig. 15), depicted in profile, are painted with a dark pigment. The high signal of iron in the black area suggests the possible use of an iron based black. Alternatively, a carbon black may have been used. Here too, traces of cinnabar are detectable on the lacrimal duct and a fine brushstroke of bright cinnabar was used on the upper eyelid. A carefully drawn black line indicates the eyebrow, showing the exact same composition as the iris and pupil of the eye. In all the three faces, the white of the eyeballs (sclera) has been painted using Egyptian blue, looking glowing white in the VIL image (fig. 10). The use of Egyptian blue in the white area of the eyes (sclera) was a rather common technique from the Classical up to the Roman period - both on paintings and sculptures - aiming at producing an effect of moistness and light that could revive and accentuate the gaze. Its practice has recently also been attested on large scale figurative paintings from ancient Macedonia ${ }^{56}$. Such a technical detail acquires particular significance in the field of artistic experimentations of fourth century BC painters, aiming at reproducing lifelike effects. In fact, ancient authors praise the liquidness and brightness of the eyes (for Alexander's melting gaze, see Plutarch Moralia 335; Alexander 4, 1-2; for the beauty of the liquid gaze, see Lucian's Imagines, 6-8) and in Polemon's Physiognomonics (Leiden ch. 1, A16) "good eyes" are associated with brightness and "beautiful light" 57 . Gilding was applied onto the hair and the beard of the male heads, following a similar technique as the one attested on the Aigai couch, with an undercoat of yellow ochre serving as a coloured substrate for the gold leaf. The layer of yellow ochre is visible in the areas where gold leaf is not still preserved and its identification was confirmed by the high signal of iron in the yellow area (figs 16-17). The presence of lead in almost all the paint layers examined suggests that lead white was probably used as an undercoat or/and in mixtures with pigments. The absence of lead on the ivory surface that does not preserve traces of polychromy (cheeks, nose) is probably an indication
Fig. 14. Korinos, Tomb II. Chryselephantine couch. Photomicrograph of the ivory male head Пu 4374, taken by $\mathrm{H}$. Brecoulaki. Detail of the right eye. (c) $16^{\text {th }}$ Ephorate of

Prehistoric and Classical Antiquities.

Fig. 15. Korinos, Tomb II. Chryselephantine couch. Photomicrograph of the ivory female head Пu 4375 , taken by H. Brecoulaki. Detail of the right eye.

(C) $16^{\text {th }}$ Ephorate of

Prehistoric and Classical Antiquities.
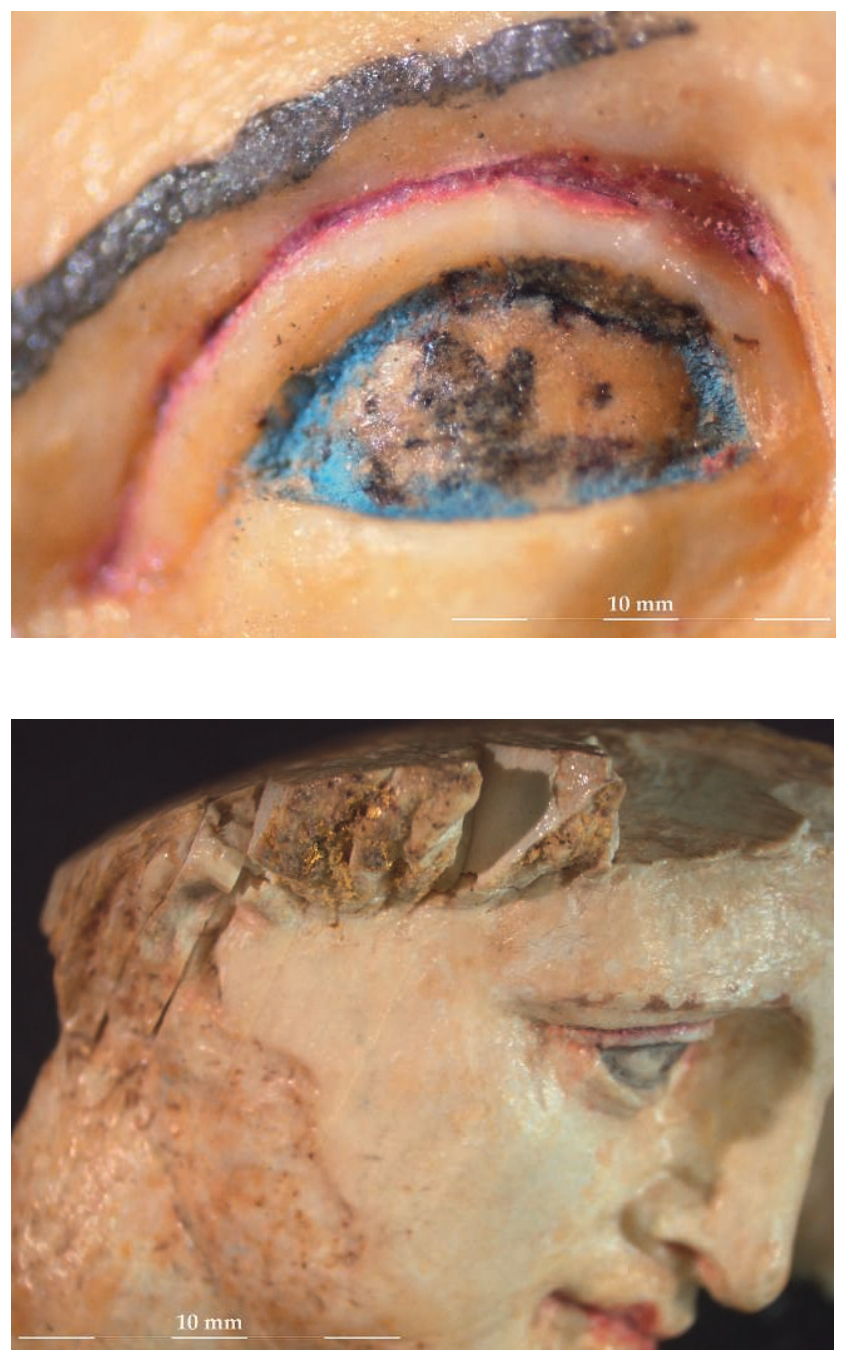

Fig. 16. Korinos, Tomb II.

Chryselephantine couch. Photomicrograph of the ivory male head Пu 4374 with traces of gilding, taken by S. Sotiropoulou. (C) $16^{\text {th }}$ Ephorate of Prehistoric and Classical Antiquities. 


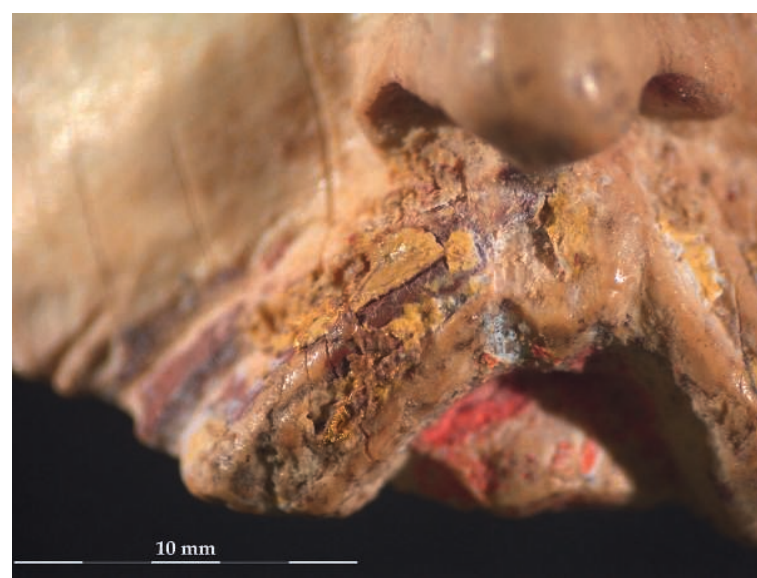

18

that painters preferred the natural creamy colour of ivory for the skin tone.

The two griffin heads from the tomb of Aghios Athanassios preserve a rich polychromy, applied in thick paint layers (figs 12-13). An extensive use of Egyptian blue is attested in the area of the eyes and the eyelids, applied as a first paint layer on top of which details of the various parts of the eyes were superimposed in different colours, leaving only the eyeballs in blue. Grains of Egyptian blue are also visible in VIL images, on parts of the neck and the beck of the griffins, where paint layers are scantily preserved. The pupil and iris of the eye are rendered in light brown, composed of an iron based ochre. On griffin 19429a (fig. 12), the upper eyelid is painted with the same brown and the lower eyelid with light pink, composed of lead white mixed with an iron based red (red ochre). A more careful treatment of the eyes is observed on griffin 19429b (fig. 13). Both the areas of the upper and lower eyelids are painted in pink, but the superior palpebral sulcus and the interior border of the eyelid are further suggested with a delicate dark brown line. For the tongue of the griffins, cinnabar was chosen, darkened today probably due to its alteration to metacinnabar ${ }^{58}$. Traces of gilding survived

Fig. 17. Korinos, Tomb II.

Chryselephantine couch.

male head Пu 4378 with

H. Brecoulaki.

( $16^{\text {th }}$ Ephorate of Prehistoric

and Classical Antiquities.

on the neck of griffin 19429a (fig. 18). The presence of iron in the analyzed area seems to confirm, here too, the use of yellow ochre as an undercoat. Contrary to the Korinos ivories, the constant presence of lead, even on parts of the griffins, where no visible traces of polychromy are preserved, seems to corroborate the fact that the entire surface was originally recovered with paint layers (either white or coloured).

The polychromy applied directly onto ivory, as is attested on the examined fragments, reflects a highly sophisticated use of colour to depict details of the facial features, with a pronounced attention to the area of the eyes, both on the human faces and the griffins. Although intermixtures of pigments are practiced, here too, as in the case of the couch of Aigai, the painters wished to produce a vivid effect of polychromy by using saturated hues of predominant contrasted colours: bright cinnabar for the lips, nostrils and eyelids and thick layers of Egyptian blue to cover the eyeballs.

$\rightarrow$

Fig. 19. Table 1:

List with analyzed samples; \#1-12 were measured with the handheld XRF analyzer, whereas the samples \#13-17 (KLF) with the scanning micro-XRF spectrometer.

The elements detected by the handheld XRF and micro-XRF analyses are classified according to their abundance in a semiquantitative manner as major, minor and trace elements.
Fig. 20. Table 2:

XRF elemental analysis results on the ivory fragments Пv 4374 Пv 4375, Пv 4378, 19429 $\alpha$ and $19429 \beta$

Fig. 18. XRF spectrum taken from the area with traces of gilding on the neck of the griffin 19429a, showing the presence of $\mathrm{Au}$ as major element.

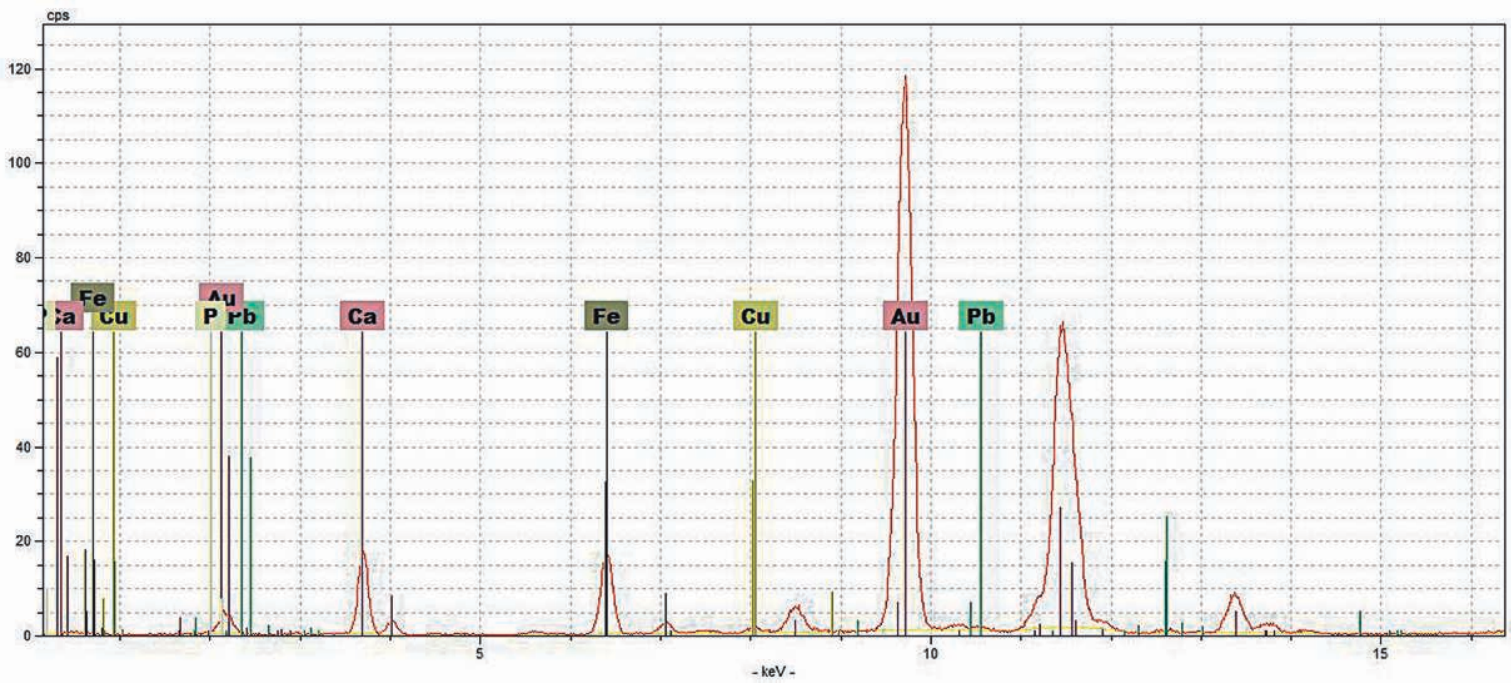


Fig. $19=$ table 1

\begin{tabular}{|c|c|c|c|c|c|c|}
\hline \multirow[t]{2}{*}{ \# } & \multirow[t]{2}{*}{ Sample Description } & \multirow[t]{2}{*}{ Colour } & \multirow[t]{2}{*}{$\begin{array}{l}\text { Analytical } \\
\text { Technique }\end{array}$} & \multicolumn{3}{|l|}{$\begin{array}{l}\text { Detected elements } \\
\text { XRF Analysis }\end{array}$} \\
\hline & & & & Major & Minor & Trace \\
\hline 1 & Tomb II, ST4A, piece 1 & Green & Handheld XRF & $\mathrm{Al}, \mathrm{Si}, \mathrm{P}, \mathrm{Ca}, \mathrm{Fe}, \mathrm{Cu}, \mathrm{As}$ & $\mathrm{S}, \mathrm{Cl}, \mathrm{Fe}$ & $\mathrm{Sr}$ \\
\hline 2 & Tomb II, ST4A, piece 2 & Green & Handheld XRF & $\mathrm{Al}, \mathrm{Si}, \mathrm{Ca}, \mathrm{Fe}, \mathrm{Cu}, \mathrm{As}$ & $\mathrm{S}, \mathrm{Cl}, \mathrm{Fe}$ & $\mathrm{Sr}$ \\
\hline 3 & Tomb II, ST4A, piece 3, black encrustation & Black & Handheld XRF & $\mathrm{Al}, \mathrm{Si}, \mathrm{P}, \mathrm{Ca}, \mathrm{Fe}, \mathrm{Cu}, \mathrm{As}, \mathrm{Pb}$ & & $\mathrm{Cr}, \mathrm{Zn}, \mathrm{Rb}, \mathrm{Sr}$ \\
\hline 4 & Tomb II, ST4A, piece 3, back side & Green & Handheld XRF & $\mathrm{Al}, \mathrm{Si}, \mathrm{P}, \mathrm{Ca}, \mathrm{Fe}, \mathrm{Cu}$ & $\mathrm{S}, \mathrm{Cl}, \mathrm{Pb}$ & $\mathrm{Cr}, \mathrm{Zn}, \mathrm{As}, \mathrm{Br}, \mathrm{Rb}, \mathrm{Sr}$ \\
\hline 5 & Tomb II, ST4A, piece 1 , back side & White & Handheld XRF & $\mathrm{Al}, \mathrm{Si}, \mathrm{S}, \mathrm{Ca}, \mathrm{Fe}, \mathrm{Cu}, \mathrm{As}$ & & $\mathrm{Sr}$ \\
\hline 6 & Tomb II, ST4A, piece 1 , back side & White & Handheld XRF & $\mathrm{Al}, \mathrm{Si}, \mathrm{S}, \mathrm{Ca}, \mathrm{Fe}, \mathrm{Cu}, \mathrm{As}$ & & $\mathrm{Sr}$ \\
\hline 7 & Tomb II, G4a, T. II chamber, piece 4 & Black & Handheld XRF & Al, Si, P, S, Ca, Cu & $\mathrm{Cr}, \mathrm{Mn}, \mathrm{Fe}, \mathrm{Pb}$ & $\mathrm{Br}, \mathrm{Sr}$ \\
\hline 8 & Tomb II, G4a, T. II chamber, piece 4, back side & Black & Handheld XRF & $\mathrm{Al}, \mathrm{Si}, \mathrm{P}, \mathrm{S}, \mathrm{Ca}, \mathrm{Cu}$ & $\mathrm{Cr}, \mathrm{Mn}, \mathrm{Fe}, \mathrm{Pb}$ & $\mathrm{Br}, \mathrm{Sr}$ \\
\hline 9 & Tomb II, G4a, T. II chamber, piece 5 & Pink & Handheld XRF & $\mathrm{Al}, \mathrm{Si}, \mathrm{S}, \mathrm{Ca}, \mathrm{Hg}, \mathrm{Au}$ & $\mathrm{K}, \mathrm{Ti}, \mathrm{Fe}, \mathrm{Cu}$ & $\mathrm{Sr}$ \\
\hline 10 & Tomb II, G4a, T. II chamber, piece 6 & Black & Handheld XRF & $\mathrm{Si}, \mathrm{P}, \mathrm{S}, \mathrm{Ca}, \mathrm{Cu}$ & $\mathrm{Cr}, \mathrm{Mn}, \mathrm{Fe}, \mathrm{Pb}$ & $\mathrm{Br}, \mathrm{Sr}$ \\
\hline 11 & Tomb II, G4a, T. II chamber, piece 7 & Green & Handheld XRF & $\mathrm{Si}, \mathrm{P}, \mathrm{Ca}, \mathrm{Fe}, \mathrm{Cu}, \mathrm{As}$ & $\mathrm{S}, \mathrm{Cl}$ & $\mathrm{Sr}$ \\
\hline 12 & Tomb II, G4a, T. II chamber, piece 7 & Pink & Handheld XRF & $\mathrm{Al}, \mathrm{Si}, \mathrm{P}, \mathrm{Ca}$ & $\mathrm{S}, \mathrm{Cl}, \mathrm{Fe}, \mathrm{Cu}, \mathrm{As}, \mathrm{Au}, \mathrm{Pb}$ & $\mathrm{Sr}$ \\
\hline 13 & KLF1 & Yellow & Micro-XRF & $\mathrm{Ca}, \mathrm{Fe}, \mathrm{Au}$ & $\mathrm{Cu}, \mathrm{Zn}, \mathrm{Pb}$ & $\mathrm{Sr}$ \\
\hline 14 & KLF2 & Green & Micro-XRF & $\mathrm{Ca}, \mathrm{Cu}, \mathrm{As}$ & $\mathrm{Cr}, \mathrm{Fe}$ & $\mathrm{Sr}, \mathrm{Zr}, \mathrm{Pb}$ \\
\hline 15 & KLF5.1 & Green & Micro-XRF & $\mathrm{Ca}, \mathrm{Fe}, \mathrm{Cu}, \mathrm{As}$ & $\mathrm{Cr}$ & $\mathrm{Sr}, \mathrm{Zr}$ \\
\hline 16 & KLF5.2 & Black & Micro-XRF & $\mathrm{Ca}, \mathrm{Fe}, \mathrm{Cu}, \mathrm{Pb}$ & $\mathrm{Cr}$ & $\mathrm{As}, \mathrm{Br}, \mathrm{Sr}, \mathrm{Zr}$ \\
\hline 17 & KLF6.1 & Pink & Micro-XRF & $\mathrm{Fe}$ & $\mathrm{Cu}, \mathrm{Ba}, \mathrm{Pb}$ & $\mathrm{Br}, \mathrm{Sr}$ \\
\hline
\end{tabular}

Fig. $20=$ table 2

\begin{tabular}{|c|c|c|c|c|c|c|}
\hline \multirow[t]{2}{*}{ Catalogue number } & \multirow[t]{2}{*}{ Position description } & \multirow[t]{2}{*}{ Colour } & \multicolumn{2}{|c|}{ Detected elements } & \multirow[t]{2}{*}{ Suggested pigments } & \multirow[t]{2}{*}{ Remarks } \\
\hline & & & Major & Minor & & \\
\hline \multirow{4}{*}{ Пv 4374} & Ground & Ivory & $\mathrm{Ca}, \mathrm{P}$ & $\mathrm{Fe}, \mathrm{Cu}$ & & No $\mathrm{Pb}$ \\
\hline & Lips & Red & $\mathrm{Ca}, \mathrm{P}, \mathrm{Pb}, \mathrm{Hg}, \mathrm{S}$ & $\mathrm{Fe}, \mathrm{Cu}, \mathrm{Ba}$ & Cinnabar & \\
\hline & Eyeball & Blue & $\mathrm{Ca}, \mathrm{Pb}, \mathrm{Cu}, \mathrm{Fe}$, & $\mathrm{Ba}$ & Egyptian blue & \\
\hline & Pupil of the eye & Brown & $\begin{array}{l}\mathrm{Ca}, \mathrm{P}, \mathrm{Pb}, \mathrm{Fe}, \mathrm{Hg} \\
\mathrm{S}, \mathrm{Cu}\end{array}$ & $\mathrm{Ba}$ & Red ochre (+cinnabar) & \\
\hline \multirow{5}{*}{ Пv 4375} & Cheek (ground) & Ivory & $\mathrm{Ca}, \mathrm{P}$ & & & $\mathrm{No} \mathrm{Pb}$ \\
\hline & Lips & Bright red & $\mathrm{Ca}, \mathrm{P}, \mathrm{Pb}, \mathrm{Hg}, \mathrm{S}$ & $\mathrm{Cu}, \mathrm{Ba}$ & Cinnabar & \\
\hline & Eyeball & Blue & $\mathrm{Cu}, \mathrm{Ca}, \mathrm{P}, \mathrm{Pb}, \mathrm{Si}$ & & Egyptian blue & \\
\hline & Pupil of the eye & Black & $\mathrm{Ca}, \mathrm{P}, \mathrm{Pb}, \mathrm{Fe}, \mathrm{Cu}$ & & Iron based black? & \\
\hline & Eyebrow & Black & $\mathrm{Ca}, \mathrm{P}, \mathrm{Pb}, \mathrm{Fe}, \mathrm{Cu}$ & & & \\
\hline \multirow{3}{*}{ Пv 4378} & Nose & & $\mathrm{Ca}, \mathrm{P}$ & $\mathrm{Fe}, \mathrm{Cu}, \mathrm{Ba}$ & & No $\mathrm{Pb}$ \\
\hline & Lacrimal duct & Bright red & $\begin{array}{l}\mathrm{Ca}, \mathrm{P}, \mathrm{Pb}, \mathrm{Fe}, \mathrm{Cu}, \\
\mathrm{Hg}, \mathrm{S}\end{array}$ & $\mathrm{Ba}$ & Cinnabar and red ochre & \\
\hline & Beard & Gold & $\mathrm{Ca}, \mathrm{P}, \mathrm{Au}, \mathrm{Fe}$, & $\mathrm{Cu}, \mathrm{Pb}, \mathrm{Ba}$, & Gold on top of yellow ochre & \\
\hline \multirow{8}{*}{$19429 \alpha$} & Ground (back side) & Ivory & $\mathrm{Ca}, \mathrm{P}, \mathrm{Pb}$ & $\mathrm{Cu}, \mathrm{Fe}$ & & \\
\hline & Ground (beak) & Ivory & $\mathrm{Ca}, \mathrm{P}, \mathrm{Pb}$ & $\mathrm{Cu}, \mathrm{Fe}$ & & \\
\hline & Tongue & Red & $\mathrm{Ca}, \mathrm{P}, \mathrm{Pb}, \mathrm{Hg}, \mathrm{S}$, & $\mathrm{Fe}, \mathrm{Cu}$ & Cinnabar & \\
\hline & Eyeball & Blue & $\mathrm{Ca}, \mathrm{Fe}, \mathrm{Pb}$, & Cu, Si, P & Egyptian blue & \\
\hline & Pupil of the eye & Light red & $\mathrm{Ca}, \mathrm{P}, \mathrm{Pb}, \mathrm{Fe}$, & $\mathrm{Cu}, \mathrm{Hg}$ & Red ochre & \\
\hline & Lower eyelid & Pink & $\mathrm{Pb}, \mathrm{Ca}, \mathrm{P}, \mathrm{Fe}$, & $\mathrm{Cu}, \mathrm{Hg}$ & Red ochre mixed with lead white & \\
\hline & $\mathrm{Pb}$ is detected in high amount & & & & & \\
\hline & Neck & Gold leaf & $\mathrm{Au}, \mathrm{Ca}, \mathrm{Fe}$ & $\mathrm{Cu}, \mathrm{Ag}, \mathrm{Pb}$ & Gold and yellow ochre & $\mathrm{Ag}$ is associated with $\mathrm{Au}$ \\
\hline $19429 \beta$ & Pupil of the eye & Light red & $\mathrm{Ca}, \mathrm{P}, \mathrm{Pb}, \mathrm{Fe}$, & $\mathrm{Cu}$ & Red ochre mixed with lead white & \\
\hline
\end{tabular}




\section{Conclusion}

The polychromy on the tiny ivory faces examined was used to enhance a quasi "dramatic" effect of shadows and light, already achieved by the deep carving of the facial features. Smooth tonal passages and soft chiaroscuro effects, as attested on larger scale Hellenistic and Roman statues ${ }^{59}$, were not practiced, presumably due to the requirements imposed by their extremely reduced size, that should make themselves visible in the receding frames of the sumptuously decorated furniture of which they were components. The painters who worked on the ivory polychromy used the same gamut of pigments as those who produced bi-dimensional paintings to decorate funerary Macedonian monuments. However, the methods of their application diverge and rarely do we encounter a deliberate use of pure pigments in figural painting. In general, pure pigments are only reserved to areas serving as backgrounds and mixtures of pigments are constantly practiced, either through physical blending or with superimposed paint layers.

The Macedonian couches with their preserved ivory reliefs offer today the most tangible and precious evidence of Hellenistic ivory sculptural polychromy. Standing out as luxurious artifacts within the material culture of fourth century Macedonia, they were used as markers of social status of the Macedonian elite, already before the expedition of Alexander the Great in the East. Imported ivory, precious metals and rare minerals were combined by skillful craftsmen and talented artists to produce unique pieces of furniture, shining like jewels. The golden backgrounds of the couches propagated physical light inside the andrones through their metallic surface and perpetuated metaphysical, "divine light" ${ }^{60}$, within the dark universe of the tombs. The high level of technical competence and sophistication in both carving and polychromy, reflect the assimilated experience of local workshops, in charge of producing such lavish furniture for their distinguished clientele.

\section{Acknowledgments}

Warm thanks are due to A. Kottaridi (Director of the $17^{\text {th }}$ Ephorate of Prehistoric and Classical Antiquities), M. Besios and M. Tsimbidou-Avloniti ( $16^{\text {th }}$ Ephorate of Prehistoric and Classical Antiquities) for their permission to study the material from Aigai, Pydna and Aghios Athanassios. Our gratitude is also expressed to Ralf Bernd Kaiser (Section Head at the Physics Section of the IAEA) for providing permission for the use of the IAEA handheld XRF analyser, P. Adam-Veleni (Director of the Archaeological Museum of Thessaloniki), N. Kapizioni and D. Ignatiadou, for facilitating our work at the Archaeological Museum of Thessaloniki and for their kind assistance.

\section{Notes}

1. On the literary evidence for couches, see Andrianou, 2009, p. 31-34. K. Sismanidis (Sismanidis, 1997) has presented the bed and bed-shaped structures from Macedonian tombs, mainly made of stone. The kline in the main chamber (thalamos) of the tomb of Philip II at Aigai is unique that it received the weapons and not the ashes of the deceased (Andronikos, 1984, p. 121-131)

2. The dimensions of funerary beds, regardless of the material employed in their construction, are usually an average of $2 \mathrm{~m}$ in length and $1 \mathrm{~m}$ in height and width (Andrianou, 2009, p. 42; Sismanidis, 1997, p. 189-192).

3. On the glass elements used for the decoration of the funerary couches, see Ignatiadou, 2007, p. 219-227.

4. For the decoration of the couches, see Kottaridi, 1999, p. 129-134, figs 8-11; Kottaridi, 2011, p. 80-90; Kottaridi, 2013, p. 296-314. 2010

5. Rhomiopoulou and Schmidt-Dounas,

6. Prinou, 2000; Besios, 2010.

7. Tsimbidou-Avloniti, 2005.

8. Kottaridi, 2011, p. 83.

9. For the materials and techniques of

ivory statuary, see Lapatin, 2001: 7-21.

10. Parisinou, 2000.

11. Lapatin, 2001, p. 63-88.

12. Lapatin, 2001, p. 10-12; Tartaron, 2013, p. 27, 30, 44,

13. Philostratos clearly expresses his preference for ivory statues in his word Vita
Apollonii (5.22): "As for myself I would far rather enter a temple, no matter how small, and behold in it a statue of ivory and gold, than behold one of pottery and bad workmanship in a vastly larger one". 14. Brecoulaki, 2014, p. 19-25; Brecoulaki, Kavvadias, Verri, 2014.

15. Gaunt, 2013.

16. Brecoulaki, 2006, p. 53-76.

17. Sismanidis, 1997, figs 1-7; for the

pigments, see Brecoulaki, 2006, p. 362-370.

18. Lapatin, 2001, p. 18.

19. For the surviving archaeological evidence for chryselephantine statuary, see Lapatin, 1996; 2001

20. As are the figures at the battle scenes decorating the long sides of the couch in the antechamber of Philip' s II tomb at Aigai (Kottaridi, 2011, p. 81).

21. "Here are the statues of Philip and Alexander, and with them is Amyntas, Philip's father. These works too are by Leochares and are of ivory and gold as are the statues of Olympias and Eurydike".

22. An ivory industry was probably active in Alexandria during the Hellenistic period and a number of small-scale ivories are considered as products of Alexandrian workshops (Rodziewicz, 1971).

23. Ptolemy II Philadelphos commissioned chryselephantine statues of his parents, Ptolemy I Soter and Berenike I. An ivory frieze adorned the principal cabin of the luxurious barge of Ptolemy IV Philopater (221-204 BC, Ath. 5.205c) and an ivory portrait of the Hellenistic ruler Nikomedes I of Bithynia is reported by
Pausanias (5.12.7) in the temple of Zeus at Olympia.

24. For excellent photographs of the couch and details with polychromy see Kottaridi, 2013, p. 300-301.

25. For the identification of the heads with portraits of Philip II and Alexander see: Andronikos, 1984, p. 122-131; Kottaridi, 2011, p. 88; Smith, 1988 , p. 62-63.

26. Brecoulaki, 2006, vol. II, p. 158. In this publication, the author has erroneously described the couch as belonging to the antechamber of the room, instead of the main chamber.

27. Brecoulaki, 2006, p. 128-129.

28. X-ray Spectrometry Laboratory, Institute of Nuclear Physics, NCSR "Demokritos".

29. The analyzer is composed by a miniaturized air-cooled Silver anode transmission X-ray tube and a large area Silicon Drift Detector $\left(30 \mathrm{~mm}^{2}\right)$. Two excitation conditions were selected to optimize the analytical range and sensitivity of the analyses; one that utilizes a filtered excitation beam at $50 \mathrm{kV}$ operational voltage (elements analyzed from atomic number $\mathrm{Z}=19$ ) and a second unfiltered one targeting the detection of light elements (Al, Si, P, S) with the X-ray tube operating at $8 \mathrm{kV}$. An integrated camera documents the analysis area at each analysis point, whereas, for all the measurements, the size of the beam footprint was selected to be about $3 \mathrm{~mm}$ in diameter (Karydas et al., 2014).

30. The spectrometer includes a microfocus Rh-anode X-ray tube (spot size 
$50 \times 50 \mu \mathrm{m}, \max 50 \mathrm{kV}, \max 1 \mathrm{~mA}, 30-\mathrm{W}$ maximum power consumption, $0.2 \mathrm{~mm}$ thickness of the tube Be window) and a polycapillary X-ray lens as a focusing optical element with a focal distance of about 21.2 $\mathrm{mm}$. The X-ray detection chain consists of a thermoelectrically cooled $10 \mathrm{~mm}^{2}$ silicon drift detector (X-Flash) with 146 eV FWHM at $10 \mathrm{kcps}$ coupled with a digital signal processor. A color CCD camera combined with a white LED and a spot laser beam assures reproducible positioning of the measuring probe, as well as visualization and documentation of the analyzed area. Three stepping motors coupled with the spectrometer head allow three-dimensional movement for elemental mapping and precise setting of the analysis spot at the focal distance of the polycapillary lens. The scans over the fragments were performed at the following operational conditions: $50 \mathrm{kV}$, $600 \mu \mathrm{A}, 50 \mathrm{~s} / \mathrm{step}, 100 \mu \mathrm{m}$ step size with a total scanned area of about $0.7 \mathrm{~mm} \times 0.7$ $\mathrm{mm}$. A filter consisting of $\mathrm{Ti}$ and $\mathrm{Pd}$ was used to improve the monochromaticity of the excitation beam and avoid the presence of diffraction patterns in the spectrum. The spatial resolution of the micro-XRF spectrometer is $76-31 \mu \mathrm{m}$ for characteristic X-rays having energies between 4.5 and 22 $\mathrm{keV}$, respectively (Karydas, Anglos and Harith, 2008).

31. On the properties and chemical composition of the pigments, see Brecoulaki 2000; Brecoulaki and Perdikastsis, 2002; Brecoulaki, 2006, p. 399-432.

32. On the use and properties of stucco, see Lapatin, 2001, p. 19-20.

33. Brecoulaki, 2014, p. 16-17; Trinquier, 2013.

34. Such as the sources of cinnabar in the localities of Yugoslavia (Eastaugh et al., 2004, p. 105)

35. The traces of bromine detected into the paint layer of sample (KLF 6.1) may suggest a possible identification with murex purple, although also in other positions $\mathrm{Br}$ was present (see table 1, fig. 19). However, such evidence does not allow any conclusive argument for the identification of the pigment and further analysis for the detection of organic dyes are required.

36. Brecoulaki, 2000, p. 151-152.

37. Brecoulaki, 2006, p. 421-422; Lilimbaki-Akamati, 2007, p. 166-167; Perdikatsis, Maniatis and SaatsoglouPaliadeli, 2002, p. 250.

38. Brecoulaki, 2006, p. 400-405

39. Bourgeois, Jockey, 2005; 2007; Bourgeois, Jeammet, Pagès-Camagna, 20122013.

40. Bourgeois, Jeammet and PagèsCamagna, forthcoming. p. 153

41. Brecoulaki and Perdikatsis, 2002

42. Eastaugh, Walsh, Chaplin and Siddal, 2004, p. 120.

43. The micro-XRF experimental conditions were as follows: $50 \mathrm{kV}, 600 \mu \mathrm{A}$, $50 \mathrm{~s} / \mathrm{step}, 100 \mu \mathrm{m}$ step size with a total scanned area of about $0.7 \mathrm{~mm} \times 0.7 \mathrm{~mm}$.

44. Jambor, Owens and Dutrizac, 1980

45. Karydas et al., 2014.

46. In that case with green earth (and less commonly with malachite). Brecoulaki forthcoming. A comparable treatment using grains of Egyptian blue in order to obtain cool hues in the flesh is observed on a variety of Greco-Roman panel portraits from Egypt (Verri, Opper and Lazzarini, 2014, p. 164165).

47. Besios, 1994, p. 177; Besios, 2010, p. $277-283$

48. Prinou, 2000.

49. Tsimbidou-Avloniti, 1997, p. 432; Tsimbidou-Avloniti, 2005, p. 104-105; 161165, pl. 48b, fig. 21

50. The measuring head, which is the main part of the Artax 400, consists of: a metal ceramic air-cooled - molybdenum tube, a Silicon Drift - peltier cooled Detector (SDD) and a Charge Coupled Device (CCD) camera for the visual inspection of the sample. The camera displays an area of approximately 12 x 6 $\mathrm{mm}^{2}$ of the sample surface on the computer monitor. The X-ray beam is restricted by a collimator. The lateral resolution is between $200 \mu \mathrm{m}$ and $1500 \mu \mathrm{m}$, depending on the type of the collimator used. At the presen study was used the $650 \mu \mathrm{m}$ collimator. For the determination of elements with lower atomic number, the excitation conditions are improved using an helium $(\mathrm{He})$ gas purging system (Stuart, 2007).

51. Bronk, Rohrs, Bjeoumikhov, Langhoff, Schmalz, Wedell, Gorny, Herold and Waldschlager, 2001.

52. Verri, 2009

53. Accorsi, Verri, Bolognesi, Armaroli, Clementi, Miliani and Romani, 2009.

54. LED PAR lights were used for excitation (Eurolite LED PAR56 RGB spots 20W, (151 LEDs), $45^{\circ}$ ), of which the red LEDs were used selectively), a visually opaque polyester filter (LEE polyester IR filter 87 - visually opaque filter with transmission starting at 730) was placed in front of the lens of the digital photographic camera (SONY camera A300, 10.2 Mpixels) to absorb unwanted visible light. The camera's built-in IR-blocking filter, which is placed in front of the CCD sensor, was removed. For all shots, a specifically designed Egyptian-blue scale was placed next to the object. The scale consists of colour gradations of Egyptian blue resulting from mixing pure Egyptian blue pigment with white in a gradually increased concentration. The scale allows a rough estimate of the relative concentration of Egyptian blue in the sample examined.

55. For the use of cinnabar on other ivory heads, see Lapatin, 2001, p. 19.

56 . VIL imaging performed by G. Verr has attested the use of Egyptian blue in the eyeballs of the hunters on the facade of the tomb of Philip II and on the large-scale figures of the tomb of Aghios Athanassios.

57. Brecoulaki forthcoming.

58. Holley, McQuillan, Craw, Kim and Sander, 2007.

59. Verri, Opper and Lazzarini, 2014. 60. Parisinou, 2000

\section{Bibliography}

Accorsi, G., Verri G., Bolognesi M., Armaroli N., Clementi C., Miliani C. and Romani A., 2009, "The exceptional nearinfrared luminescence properties of cuprorivaite (Egyptian blue)", Chemical Communications 23, p. 3392-3394.

Andrianou D., 2009, The furniture and furnishings of ancient Greek houses and tombs, Cambridge University Press, Cambridge.

Andronikos M., 1984, Vergina. The Royal Tombs, Ekdotike Athinon, Athens.

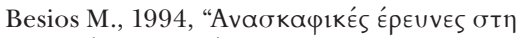
Bópєıа Пıєрía”, AEMTh 5 (1991), p. 171-178.

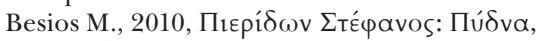

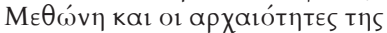
Bópeıas Пıєрías, A.F.E. editions, Katerini.

Bourgeois B., Jockey Ph., 2005, «La dorure des marbres grecs. Nouvelle enquête sur la sculpture hellénistique de Délos", Journal des savants 2 , p. 253-316.

Bourgeois B., Jockey Ph., 2007, «Le marbre, l'or et la couleur. Nouveaux regards sur la polychromie de la sculpture hellénistique de Délos» in S. DecampsLequime (ed.), Peinture et couleur dans le monde antique, éditions du Louvre, Paris, p. 176-177.

Bourgeois B., Jeammet V., Pagès-Camagna S., 2012-2013, « Color Siderum. La dorure des figurines en terre cuite grecques aux époques hellénistique et romaine », BCH 136-137, p. 483-510.

Bourgeois B., Jeammet V., Pagès-Camagna S., forthcoming, "Greek gilded wood: An exceptional polychrome peplophoros from Kertch", in $\mathrm{H}$. Brecoulaki, S. Sotiropoulou (eds), Proceedings of the International Round Table on Greek and Roman Sculptural and Architectural Polychromy, Athens $7^{\text {th }}-8^{\text {th }}$ November 2013.

Brecoulaki H., 2000, «Sur la techné de la peinture grecque ancienne d'après les monuments funéraires de Macédoine", BCH 124, p. 189-216.

Brecoulaki H., 2014, "Precious Colours in Ancient Greek Polychromy and Painting: Materials Aspects and Symbolic Values", Revue Archéologique 2014/1, n ${ }^{\circ}$ 57, p. 1-36.

Brecoulaki H., forthcoming, «Saisir la ressemblance ou surpasser le modèle? La représentation de la figure humaine dans la peinture grecque et la tradition du portrait peint dans l'Égypte grécoromaine», in P. L. de Bellefonds, É. Prioux, A. Rouveret (eds)., Mémoire, déconstruction, recréation dans les arts visuels et la poésie de l'époque hellénistique au premier siècle après J.-C., Colloque de l'ANR CAIM, Paris, 10-12 mai 2012, in press.

Brecoulaki H., Perdikatsis V., 2002, "Ancient wall - painting on Macedonian chamber tombs and cist graves, IV - III c. BC: A comparative study on the use of color", in M. Tiverios, D. Tsiafakis (eds) Color in Ancient Greece, Proceedings of the International Symposium, 12-16 April 
2000, The Aristoteleian University of Thessaloniki, Thessaloniki, p. 147-154.

Brecoulaki H., Kavvadias G., Verri G., 2014, "Colour and Luxury. Three Classical Painted Marble Pyxides from the Collection of the National Archaeological Museum of Athens", in J. S. Østergaard and A. M. Nielsen (eds.), Transformations: Classical Sculpture in Colour, Ny Carlsberg Glyptotek, Copenhagen, p. 152-165.

Bronk H., Rohrs S., Bjeoumikhov A., Langhoff N., Schmalz J., Wedell R., Gorny H.-E., Herold A. and Waldschlager U., 2001, «Artax - a new mobile spectrometer for EDXRF spectrometry on art \& archaeological objects ", Frescenius J. Anal Chem 371, p. 307-316.

Eastaugh N., Walsh V., Chaplin T., Siddal R., 2004, Pigment Compendium: A Dictionary of Historical Pigments, Elsevier, Oxford.

Holley E. A., McQuillan A. J., Craw D., Kim J. P. and Sander G, 2007, "Mercury mobilization by oxidative dissolution of cinnabar $(\alpha-\mathrm{HgS})$ and metacinnabar ( $\beta$-HgS)", Chemical Geology 240, p. 313-325.

Ignatiadou D., 2007, « Le verre incolore, élément du décor polychrome du mobilier funéraire de Macédoine ", in S. Descamps-Lequime (ed.), Peinture et couleur dans le monde grec antique, éditions du Louvres, Paris, p. 219-227.

Gaunt J., 2013, "The Classical marble pyxis and Dexilla's dedication”, R.B. Kohel (ed.), AMILLA, The Quest for Excellence, Studies presented to Guenter Kopcke in Celebration of his 75th Birthday, Philadelphia, INSTAP Academic Press, p. 381-398.

Jambor J. L., Owens D. R. and Dutrizac J. E., 1980, "Solid solution in the adelite group of arsenates", Canadian Mineralogist, vol. 18, p. 191-195.

Karydas A. G., Anglos D. and Harith M. A., 2008, "Mobile spectrometers for diagnostic microanalysis of ancient metal objects", in V. Argyropoulos (ed.), Metals and Museums in the Mediterranean: Protecting, Preserving and Interpreting, Publications of the TEI of Athens, 2008, p. 141-177.

Karydas A. G., Brecoulaki H., Sokaras D., Wrobel P., Kantarelou V. and Kaiser R. B., 2014, "X-ray characterization of pigments from the Royal tomb of Philip II, Aigai, Macedonia”, Poster presentation at the European X-Ray Spectrometry Conference, Bologna, 14-18 June 2014.

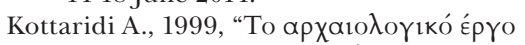

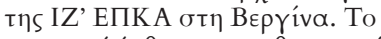

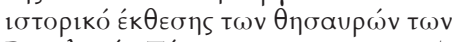

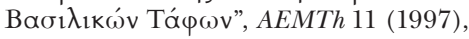
p. 129-134.

Kottaridi A., 2011, Macedonian Treasures: A Tour through the Museum of the Royal Tombs of Aigai, Kapon Editions, Athens.

Kottaridi A., 2013, Aigai: The royal metropolis of the Macedonians, John S. Latsis Public Benefit Foundation, Athens.

Lapatin K. D. S., 1996, "The Ancient Reception of Pheidias' Athena Parthenos: The Physical Evidence in Context", in L. Hardwick and S. Ireland (eds), The January Conference 1996: The Reception of Classical Texts and Images (Milton Keynes), p. 1-20.

Lapatin K. D. S., 2001, Chryselephantine Statuary in the Ancient Mediterranean World, Oxford Monographs on Classical Archaeology, Oxford University Press, Oxford.

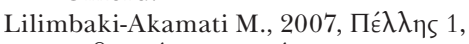

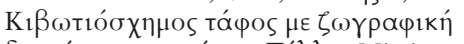

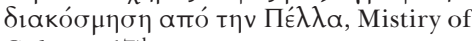
Culture, $17^{\text {th }}$ Ephorate of Prehistoric and Classical Antiquities, Thessaloniki.

Parisinou E., 2000, The Light of the Gods. The Role of Light in Archaic and Classical Greek Cult, Duckworth, London.

Perdikatsis V., Maniatis I., SaatsoglouPaliadeli Ch., 2002, "Characterisation of the Pigments and the Painting Technique used on the Vergina Stelae", in M. Tiverios, D. Tsiafakis (eds) Color in Ancient Greece, Proceedings of the International Symposium, 12-16 April 2000, The Aristoteleian University of Thessaloniki, Thessaloniki, p. 245-258.

Rhomiopoulou K., Schmidt-Dounas B., Das Palmettengrab in Lefkadia, Mitteilungen des Deutschen Archäologischen Instituts, Athenische Abteilung, 21.Beiheft, Verlag Philipp von Zabern, Mainz am Rhein.

Rodziewicz E., 1971, "Greek Ivories of the Hellenistic Period", Travaux du Centre d'archéologie méditerranéenne de l'Académie polonaise des sciences II: Etudes et Travaux 5, p. 72-89.

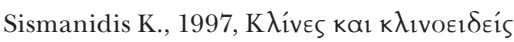

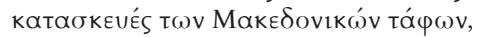
Archaeological Receipts Fund, Athens.

Smith R. R. R., 1988, Hellenistic Royal Portraits, Oxford University Press, Oxford.

Stuart B., 2007, Analytical techniques in material conservation, John Wiley \& Sons Ltd, West Sussex.

Tartaron T., 2013, Maritime Networks in the Mycenaean World, Cambridge Universtity Press, Cambridge.

Trinquier J., "Cinnabaris et "sang-dragon": le "cinabre" des Anciens entre minéral, vététal et animal », Revue Archéologique 2013/2, nº 56, p. 305-346.

Tsimbidou-Avloniti M., 1997, “Oı тацıкоí

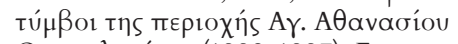

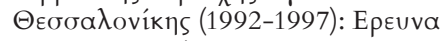

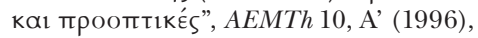
p. $427-442$.

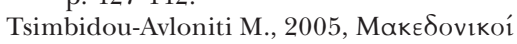

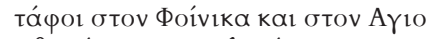

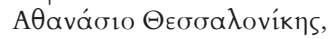
Archaeological Receipts Fund, Athens.

Verri, G., 2009, "The spatial characterisation of Egyptian blue, Han blue and Han purple by photo-induced luminescence digital imaging”, Analytical and Bioanalytical Chemistry 394 (4), p. 1011-1021.

Verri G., Opper Th. and Lazzarini L., 2014, "In picturae modum variata circumlitio?: the reconstruction of the polychromy of a Roman ideal female head (Treu Head)", in P. Liverani, Santamaria U. (eds), Diversamente bianco. La policromia della scultura romana, Edizioni Quasar, Rome, p. 149-184.

\section{Unpublished document}

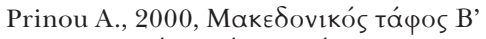
Kopivoú Пıєрías. Про́табך

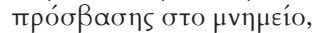

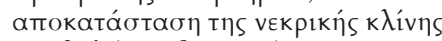

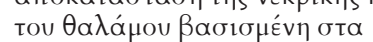

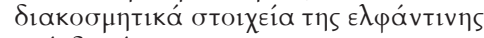

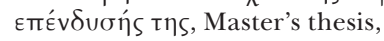
University of Thessaloniki (unpublished). 